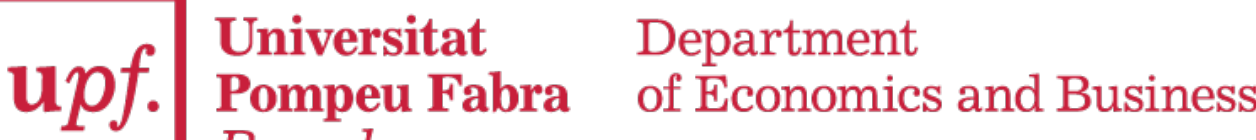 Barcelona
}

Economics Working Paper Series

Working Paper No. 1610

\section{Fiscal multipliers and foreign holdings of public debt}

Fernando Broner, Daragh Clancy, Aitor Erce and Alberto Martin

Updated version: December 2018

(December 2017) 


\title{
Fiscal Multipliers and Foreign Holdings of Public Debt*
}

\author{
Fernando Broner ${ }^{\dagger} \quad$ Daragh Clancy ${ }^{\ddagger} \quad$ Aitor Erce $^{\S} \quad$ Alberto Martin ${ }^{\llbracket}$
}

December 2018

\begin{abstract}
This paper explores a natural connection between fiscal multipliers and foreign holdings of public debt. Although fiscal expansions can raise domestic economic activity through various channels, they can also have crowding-out effects if the resources used to acquire public debt reduce domestic consumption and investment. These crowding-out effects are likely to be weaker when governments have access to foreign markets to place their debt, increasing the size of multipliers. We test this hypothesis on (i) post-war US data and (ii) data for a panel of 17 advanced economies from the 1980's to the present. To do so, we assemble a novel database of public debt holdings by domestic and foreign creditors for a large set of advanced economies. We combine this data with standard measures of fiscal policy shocks and show that, indeed, the size of fiscal multipliers is increasing in the share of public debt held by foreigners. In particular, the fiscal multiplier is smaller than one when the foreign share is low, such as in the U.S. in the 1950's and 1960's and Japan today, and larger than one when the foreign share is high, such as in the U.S. and Ireland today.
\end{abstract}

Keywords: sovereign debt, fiscal multiplier, foreign holdings of public debt.

JEL Classification: E62, F32, F34, F36, F41, F62, F65, G15, H63

${ }^{*}$ We thank Inês Martins, Mattia Picarelli, and Donghai Zhang for excellent research assistance. We received valuable comments from Neele Balke, Pablo Burriel, Giancarlo Corsetti, Sergio de Ferra, Johannes Pfeifer, Morten Ravn, Dmitriy Sergeyev, and participants at various conferences and seminars. Broner and Martin acknowledge support from the Spanish Ministry of Economy, Industry and Competitiveness through the I+D Excelencia grant (grant ECO2016-79823-P) and through the Severo Ochoa Programme for Centres of Excellence in R\&D grant (SEV2015-0563); from the Generalitat de Catalunya through the CERCA Programme grant (2014 SGR-830); and from the Barcelona GSE Research Network. Martin also acknowledges support from the European Research Council under EU Seventh Framework Programme (FP7/2007-2013) ERC Consolidator Grant (615651-MacroColl). These are the views of the authors and not necessarily those of the ECB or the ESM.

${ }^{\dagger}$ CREi, Universitat Pompeu Fabra, and Barcelona GSE.

¥The European Stability Mechanism.

$\S$ The European Stability Mechanism.

"European Central Bank, CREi, and Barcelona GSE. 


\section{Introduction}

In the aftermath of the financial crisis, fiscal policy has taken center stage in the macroeconomic debate. Ten years after the start of the crisis, most advanced economies have yet to recover fully from its effects while traditional monetary policy has lost its effectiveness as nominal interest rates are close to zero. While many of these countries initially responded to the crisis with fiscal stimuli, several of them have since implemented strict austerity measures. This has motivated a new wave of empirical research on the effects of fiscal policy, particularly on the size of fiscal multipliers. ${ }^{1}$

At the same time, most advanced economies experienced a sharp increase in public debt as they faced deep recessions and costly financial bailouts. The rise of public debt was accompanied by two key developments, especially in the Euro periphery: a re-evaluation of sovereign default risk and a decline in the share of public debt held by foreigners, as the increase in public debt was predominantly absorbed by domestic banks. Since then, a growing literature has sought to understand the determinants and macroeconomic consequences of the distribution of public debt between domestics and foreigners. ${ }^{2}$

In this paper, we argue that there is a natural connection between fiscal multipliers and the foreign holdings of public debt. The intuition is simple. There are various channels through which fiscal expansions, either increases in public spending or reductions in taxes, can raise domestic economic activity. ${ }^{3}$ But fiscal expansions can also have crowding-out effects on the domestic private sector. Probably the most important among the latter is that the resources used by the domestic private sector to acquire public debt can detract from consumption and investment. This implies that the crowding-out effect of fiscal expansions is likely to be stronger when they are financed by selling public debt to domestic (as opposed to foreign) residents, except in the extreme case in which domestic residents can fully finance these purchases from foreign sources (i.e. by selling foreign assets or by borrowing from foreigners).

Our main result is that, consistent with the previous argument, the estimated size of fiscal multipliers is increasing in the share of public debt that is in the hands of foreigners. This result holds both for the United States during the postwar period, and for a panel of advanced (OECD) economies over the last few decades. According to our estimates the public spending multiplier in the United States was significantly smaller than one in the 1950s, when the foreign share was

\footnotetext{
${ }^{1}$ See Ramey (2016) for a recent survey.

${ }^{2}$ Arsanalp and Tsuda (2012), Broner, Erce, Martin and Ventura (2014) and Brutti and Saurè (2016) provide accounts of public debt developments during the European crisis.

${ }^{3}$ For a review of these channels, see Ramey (2011a).
} 
less than 5\%, and significantly greater than one in 2014, when the foreign share was close to $50 \%$. Consistently, the estimated deficit multiplier in our sample of OECD economies also depends on the foreign share. In particular, it is smaller than one for low levels of foreign share, such as Japan's $8 \%$, and is above one for high levels of foreign share, such as Ireland's $64 \%$.

We obtain these results by following existing methodologies, both regarding the identification of fiscal shocks and the empirical specifications used to estimate their effects. Regarding fiscal shocks we use two alternative approaches: (i) Ramey and Zubairy's (2018) data on shocks to government spending in the United States, and Guajardo et al.'s (2014) data on fiscal consolidations in a group of OECD economies, both of which are based on the narrative approach, and; (ii) for the case of the United States, we also estimate shocks to government spending by using the structural VAR approach of Blanchard and Perotti (2002). Regarding the empirical methodology used to estimate multipliers, we follow Ramey and Zubairy's (2018) two-step procedure. First, we use the fiscal shocks described above to instrument the fiscal variable of interest, i.e., government spending or public deficit shocks. Second, we use this instrumented fiscal variable to estimate the corresponding multiplier. In both steps we use Jordà's (2005) local projection method.

We first use these methodologies to estimate baseline, unconditional, multipliers. We then incorporate our measures of foreign debt holdings to estimate conditional multipliers. For the case, of the United States, data on public debt holdings by foreign residents is available, at a quarterly frequency starting in 1950, from the Federal Reserve Economic Databank (FRED). For the case of 17 OECD economies, we have constructed a novel annual dataset of the allocation of public debt between domestic and foreign holders. This data has been assembled from a variety of sources, including the Balance of Payments (Financial Accounts, International Investment Positions), Monetary Surveys and data provided to us directly by our sample countries' Central Banks, Ministries of Finance and Statistical Offices.

Our data on foreign holdings of public debt reveals interesting patterns. First of all, there is significant variation across countries: in some countries, such as Canada and Japan, the share of public debt held by foreigners is consistently low, whereas in others, such as Finland and Austria, foreigners hold more than $75 \%$ of public debt towards the end of the sample. Over time, in line with the rise of financial globalization, the general pattern is one of increasing public debt in the hands of foreigners. In the United States, for instance, the share of public debt held by foreigners has increased from less than $5 \%$ in the 1950 s to close to $50 \%$ today. Although this general increase has been observed across most OECD economies throughout our sample, it has not been systematic 
over time. During the recent European debt crisis, for instance, there was a sharp decline in the share of debt held by foreigners in the euro periphery.

To fix ideas, we develop a simple model that illustrates how the size of fiscal multipliers depends on the marginal foreign share of public debt holdings, i.e., on whether the change in public debt brought about by a fiscal shock is absorbed by domestic or by foreign residents. Testing this empirically, however, is difficult because the marginal foreign share is not directly observable. One possibility would be to estimate it based on the correlation between changes in foreign holdings of public debt and changes in total public debt over a window of time following fiscal shocks. But in this case it would be hard to establish causality, because observed changes in foreign holdings are likely endogenous to ex-post economic conditions. Thus, we need an ex-ante measure of foreign share that is determined prior to the realization of the fiscal shock. ${ }^{4}$

We find that the average foreign share, i.e., the share of public debt held by foreigners before a fiscal shock, provides such a measure. Specifically, we establish that the average foreign share at the time of a fiscal shock is a good predictor of the marginal foreign share. By including this measure of the foreign share in our regressions, we find that the estimated size of fiscal multipliers is increasing in the share of public debt that is in the hands of foreigners. This results holds for the spending multiplier estimated for the United States and for the deficit multiplier estimated for our sample of OECD economies.

These findings challenge the conventional wisdom on fiscal multipliers in open economies. The common perception, inspired by the traditional Mundell-Fleming model, is that such multipliers are smaller in open economies because part of the effect of fiscal expansions on aggregate demand falls on foreign goods. ${ }^{5}$ Our findings instead point to an alternative interpretation of this inflow of foreign goods: namely, they reflect capital inflows, which help finance fiscal expansions thereby minimizing their crowding-out effects on domestic investment. In a similar vein, the common perception is that there are positive spillovers of a fiscal expansion by any one country, precisely because it raises its demand for foreign goods. Our findings instead point to a potentially negative spillover: to the extent that fiscal expansions are financed via foreign borrowing, their crowding-out effects are exported and consumption and investment are reduced elsewhere.

\footnotetext{
${ }^{4}$ For example, consider a fiscal expansion that leads to higher economic growth for reasons unrelated to the foreign share of public debt holdings. If this higher growth then results in an increase in foreign purchases of public debt, we would be classifying the event as having a high marginal foreign share. But it would be the expansionary effect of the fiscal shock that causes the high foreign share, and not the other way around.

${ }^{5}$ For empirical evidence on the relationship between multipliers and trade, see Corsetti et al. (2012), Ilzetzki et al. (2013), and Cacciatore and Traum (2018).
} 


\section{Literature review:}

Our paper is closely related to two strands of literature. The first one is the literature on the effects of fiscal policy, which has grown significantly in recent years. On the empirical side, and in the wake of the financial crisis, much of this work has argued that fiscal multipliers appeared to be larger than what we previously thought (e.g. Acconcia et al. 2013, Blanchard and Leigh 2013, Mertens and Ravn 2013). Recent work has also argued that multipliers are state contingent, being relatively large during recessions (e.g. Auerbach and Gorodnichenko 2012) and at the zero lower bound (e.g. Christiano et al. 2011 and Miyamoto et al. 2018). These findings have been partially challenged, though. Alesina and Ardagna (2013) for instance, argue that fiscal contractions can actually be expansionary. ${ }^{6}$ Ramey and Zubairy (2018), in turn, question the state-contingency of estimated multipliers.

Recently, the literature has emphasized that the effects of fiscal policy depend crucially on whether governments have access to foreign markets to place their debt. This point has been made theoretically by Broner et al. (2014), Priftis and Zimic (2015, 2018), and Farhi and Werning (2017). ${ }^{7}$ Of these, Priftis and Zimic (2018) is closest to us as they also explore this issue empirically. Our work differs from theirs in terms of both methodology and scope, however. First, they rely on an SVAR approach to identify fiscal shocks, whereas we build on the narrative approach. Second, they use ex-post changes in public debt holdings while we condition fiscal shocks on the ex-ante foreign share of public debt. In our view, as explained above, using ex-ante data makes the analysis less subject to endogeneity biases. It also has an advantage for policy purposes because it helps predict the effect of fiscal shocks. Third, we have extended substantially existing international datasets on foreign and domestic holdings of public debt.

Our paper is also related to the literature on the effects of public debt. The idea that public debt can crowd out private investment and that the extent of this crowding out depends on whether the private sector is financially constrained is of course very old (e.g. Diamond 1965 and Barro 1974). More recently, the literature has studied the connection between debt sustainability and the distribution of public debt holdings between domestic and foreign residents. One set of papers has emphasized the stabilizing role of domestic debt holdings ex ante, which raise incentives for debt repayment (e.g., Guembel and Sussman 2009, Broner and Ventura 2011, Gennaioli et al. 2014, and

\footnotetext{
${ }^{6}$ The crowding-out effects emphasized in this paper are one potential reason why fiscal contractions may be expansionary, especially when governments rely heavily on domestic financial markets.

${ }^{7}$ In a related vein, Caballero et al. (2016) and Sin (2016) argue that if the increase in safe/liquid assets associated with fiscal expansions is absorbed by foreigners their associated benefits on the domestic economy might be smaller, leading to smaller multipliers.
} 
Chari et al. 2016). Another set of papers has instead emphasized the de-stabilizing role of domestic debt holdings ex post, which might generate feedback loops between the public and private sectors in times of crisis (e.g. Acharya et al. 2014, Farhi and Tirole 2016). ${ }^{8}$

The paper is structured as follows. Section 2 describes the dataset that we use for the United States. Section 3 develops a simple model to explain the basic connection between the fiscal multiplier and foreign holdings of public debt. Section 4 and 5 respectively describe our empirical methodology and our main results for the United States. Sections 6 and 7 do the same for our panel of OECD economies. Finally, Section 8 concludes.

\section{Data}

We analyze how the foreign share of public debt holdings relates to the fiscal multiplier in the United States during the postwar period. There are two key empirical challenges for our analysis: measuring the distribution of public debt holdings between foreign and domestic residents, and identifying fiscal shocks. We next explain how we address these issues.

\subsection{Public debt holdings}

We obtained quarterly data on U.S. public debt holdings by foreign residents from 1950 from the Federal Reserve Economic Databank (FRED). We highlight some of the key features of the data here, with the full details contained in Appendix A.

Figure 1 shows the time evolution of the foreign share for the US. The figure shows that during the Bretton Woods period the share of public debt in foreign hands was low, about $5 \%$. The foreign share increased sharply after the collapse of Bretton Woods in the early 1970s, and then hovered around $20 \%$ until the mid 1990s. Since then, the foreign share has increased steadily until reaching $50 \%$ today.

\section{[INSERT FIGURE 1]}

\footnotetext{
${ }^{8} \mathrm{~A}$ related literature has focused on the role of foreign investors in determining sovereign yields. Bernanke, Reinhart and Sack (2004), Wu (2005) and Warnock and Warnock (2009), for instance, provide evidence that treasury purchases by foreign creditors reduce long-term yields.
} 


\section{$2.2 \quad$ Fiscal shocks}

Changes in fiscal policy are in general endogenous to current and expected economic conditions, making it difficult to identify truly exogenous fiscal shocks. The literature proposes two ways of overcoming this difficulty. The first is the narrative approach, which identifies exogenous shocks to fiscal variables from official documents by selecting policy announcements driven by factors other than current economic conditions. The second strategy identifies exogenous shocks to fiscal variables as the difference between observed levels and those predicted by estimated fiscal rules. We now briefly explain each of these approaches.

We use the narrative shocks to U.S. government spending provided by Ramey and Zubairy (2018), who build on Ramey's (2011b) defense news series. This series consists of news from magazines and newspapers on changes in U.S. government defense spending. Crucially, the series includes changes in spending linked to political and military events and not to the state of the economy. The fiscal shock magnitudes reflect changes to the expected present discounted value of government spending. We depict the resulting defense news shocks in Figure 2 and display their summary statistics in Table 1.

One can also identify innovations to fiscal variables as the difference between their realized values and those predicted using either structural VARs or fiscal rules. These methodologies use the identifying assumption that fiscal variables do not respond contemporaneously to shocks to their macroeconomic determinants. ${ }^{9}$ This seems reasonable for government spending, since it does not respond automatically to the state of the economy and its discretionary component is subject to decision and implementation lags. This is not the case for other components of the fiscal balance. Government investment is highly cyclical and taxes and transfers have large automatic components. The use of quarterly, rather than annual, data makes satisfying this identifying assumption more likely.

We also estimate shocks to government spending using the structural VAR approach of Blanchard and Perotti (2002). Consistent with Ramey and Zubairy (2018), we only include lagged values of government spending and GDP as macroeconomic determinants. Figure 2 displays the resulting estimated fiscal shocks, with the summary statistics included in Table 1.

We combine the identified fiscal shocks with our data on public debt holdings to assess the empirical relation between the foreign share of public debt and the size of fiscal multipliers. Before

\footnotetext{
${ }^{9}$ Auerbach and Gorodnichenko (2012) use lagged expert forecasts to eliminate the predictable component of fiscal spending innovations. We chose not to do this because experts' forecasts do not cover all of our sample.
} 
doing so, we present a simple model to demonstrate the mechanisms at play.

[INSERT FIGURE 2]

[INSERT TABLE 1]

\section{$3 \quad$ A stylized model of multipliers and sovereign debt}

We develop a simple model to illustrate how the foreign share of public debt holdings affects the size of the fiscal multiplier. The goal of the model is to highlight the main economic forces at work, and to provide a conceptual context for our empirical strategy.

\subsection{Preferences and technology}

Consider a small-open economy populated by a representative agent of mass one and a government. There are two periods, $t \in\{0,1\}$. There is a single good that can be used for consumption and investment. Agents only consume at $t=1$ and there is no uncertainty, so utility is given by

$$
U_{0}=C_{1}
$$

There are private and government production technologies. The agent receives an endowment of $E_{0}$ units of the good at $t=0$. If she invests $K$ at $t=0$ she produces

$$
Y_{1}^{P}=F(K)
$$

at $t=1$, where $F^{\prime}(\cdot)>0$ and $F^{\prime \prime}(\cdot)<0$. The government receives no endowment at $t=0$. If it invests $G$ at $t=0$ it produces

$$
Y_{1}^{G}=\gamma \cdot G
$$

at $t=1 .^{10}$

\section{$3.2 \quad$ Financial markets}

The representative agent and the government trade bonds among themselves and with an international financial market that is large and is willing to borrow and lend at a (gross) return of one.

\footnotetext{
${ }^{10}$ We assume that there are decreasing returns to scale in the private technology to ensure an interior solution. We assume that there are constant returns to scale in the public technology only to simplify the notation.
} 
As a result, the equilibrium interest rate is

$$
R=1
$$

The representative agent can borrow and lend from the international financial market, but she can only pledge a fraction $\lambda$ of her capital and of her public bond holdings. As a result, she faces the credit constraint

$$
B^{*} \geq-\lambda \cdot\left(K+B^{H}\right)
$$

where $B^{*}$ and $B^{H}$ are holdings of international and government bonds respectively, where $B^{*}<0$ implies borrowing from the international financial market. Thus, Equation (5) says that borrowing from foreigners cannot exceed the net present value of pledgeable funds. Since these funds are known during youth, the credit obtained by the private sector is riskless. The private budget constraints at $t=0$ and $t=1$ are

$$
K+B^{H}+B^{*}=E_{0} \text { and } C_{1}=Y_{1}^{P}+B^{H}+B^{*}+Y_{1}^{G}-T_{1},
$$

where $T_{1}$ are taxes at $t=1$. We assume taxes are zero at $t=0$.

The government also borrows in order to invest at $t=0$. Since taxes are zero at $t=0$, the government's budget constraints at $t=0$ and $t=1$ are

$$
G=B \text { and } B=T_{1}
$$

We assume that a fraction $\theta$ of bonds issued by the government are purchased by the international financial market, so

$$
B^{F}=\theta \cdot B \text { and } B^{H}=(1-\theta) \cdot B
$$

We take the "foreign share" $\theta$ as exogenous in this simple model, but there is a growing literature on the determinants of public debt holdings. Broadly speaking, there are two opposing forces at work. On the one hand, risk diversification pushes agents away from holding too many domestic government bonds. On the other, there are forces that push in the opposite direction, such as favored treatment of domestic agents in case of default, financial repression, macroprudential regulation, 
asymmetric information, costs of buying foreign assets, and capital controls. ${ }^{11,12}$ In any case, we are not concerned with the source of foreign share here, but rather on its effect on the size of the fiscal multiplier.

\subsection{Equilibrium and the fiscal multiplier}

Under these assumptions, it is straightforward to show that the representative agent solves

$$
\begin{gathered}
\max _{K} F(K)-K+E_{0}+Y_{1}^{G}-T_{1} \\
\text { s.t. } K \leq \frac{E_{0}}{1-\lambda}-B^{H},
\end{gathered}
$$

taking $Y_{1}^{G}, T_{1}$, and $B^{H}$ as given. The first term in the constraint is the maximum amount of resources that the agent can invest in capital and government bonds. It equals the endowment times a financial multiplier, which is increasing in the pledgeability of investments $\lambda^{13}$ If the constraint is not binding, private investment is such that the return to capital is equal to the international interest rate (i.e. one). Thus,

$$
K=\min \left\{\frac{E_{0}}{1-\lambda}-B^{H}, K^{*}\right\}
$$

where $F^{\prime}\left(K^{*}\right) \equiv 1$.

Total output at $t=1$ is therefore

$$
Y=Y^{P}+Y^{G}=F\left(\min \left\{\frac{E_{0}}{1-\lambda}-(1-\theta) \cdot B, K^{*}\right\}\right)+\gamma \cdot B
$$

\footnotetext{
${ }^{11}$ Broner et al. (2014), for instance, highlight the role of discrimination to account for the reduction in the foreign share of public debt holdings during the recent European crisis. Reinhart and Sbrancia (2015) document the use of financial repression to deal with public debt in the postwar period.

${ }^{12}$ To see how financial repression can be useful, consider a simple extension of our model in which the government is benevolent and it can choose to default on its debt in period 1. Suppose, moreover, that there are no costs to defaulting on foreigners but each unit that is defaulted on a domestic agent generates a cost of $\kappa$. In this case, the government repays its debt in equilibrium if and only if

$$
\kappa \cdot(1-\theta) \cdot b \geq \theta \cdot b \Leftrightarrow \theta \leq \frac{1}{1+\kappa} .
$$

This condition is very intuitive: the larger is the cost of defaulting on domestic agents, the lower is the amount of debt that they must hold to make repayment credible.

Of course, the representative agent does not internalize the effects of its debt holdings on enforcement, and will not willingly hold public debt as long as she is constrained. In this case, we can thus interpret $1-\theta$ as a "financial repression" threshold, which determines the minimum amount of domestic public debt that the representative is forced to hold by regulation. See Chari et al. (2016) for a related model.

${ }^{13}$ This expression is particularly simple because we assume that capital and government bonds are equally pledgeable. Our results are robust as long as neither capital nor government bonds are fully pledgeable.
} 
To calculate the fiscal multiplier we take the derivative of output $Y$ with respect to either government spending $G$ or the deficit $B .{ }^{14}$ Assuming that the credit constraint is binding, i.e., $K<K^{*}$, the multiplier equals

$$
M \equiv \frac{d Y}{d G}=\frac{d Y}{d B}=\gamma-(1-\theta) \cdot F^{\prime}(k)
$$

When the credit constraint is binding the multiplier has two terms. The first term, which is positive, is the direct effect of an increase in public spending on public output. The second term, which is negative, is the financial crowding-out effect. As long as $\theta<1$, part of the increase in public debt is absorbed by the private sector, which crowds out private investment. This effect is decreasing in foreign share $\theta$ and is the crucial element of our story. To sum up, a higher foreign share $\theta$ is associated with a higher fiscal multiplier. This is what we want to test in the empirical section.

\subsection{Foreign demand for public debt: A discussion}

Before turning to the empirical analysis, there is one question we need to address: what is the empirical counterpart to the foreign share $\theta$ ? In the model, $\theta$ is equal to both the average foreign share, i.e. $B_{t}^{F} / B_{t}$, and the marginal foreign share, i.e. $d B_{t}^{F} / d B_{t}$. In practice, this need not be the case. If they are different, it should be the marginal share that matters for the fiscal multiplier. ${ }^{15}$ That is, we would like to compare fiscal expansions that cause a large increase foreign holdings of public debt (i.e., high $d B_{t}^{F} / d B_{t}$ ) to those that do not (i.e., low $d B_{t}^{F} / d B_{t}$ ).

In practice, however, we cannot directly observe the marginal foreign share. One possibility would be to estimate it based on the correlation between changes in foreign holdings of public debt and changes in total debt over a window of time following fiscal shocks. But in this case it would be hard to establish causality, because observed changes in foreign holdings are likely endogenous to ex-post economic conditions. For example, consider a fiscal expansion that leads to higher economic growth for reasons unrelated to the foreign share in public debt holdings. If this higher growth then results in an increase in foreign purchases of public debt, we would be classifying the event as having a high marginal foreign share. But it would be the expansionary effect of the fiscal shock that causes the high foreign share, and not the other way around. ${ }^{16}$ In other words,

\footnotetext{
${ }^{14}$ The two multipliers are the same in this model because of the assumption that current taxes $T_{0}$ are constant. Our results always hold for $d Y / d B$. They also hold for $d Y / d G$ as long as $d T / d G<1$, i.e. as long increases in $G$ lead to increases in $B$.

${ }^{15}$ For example, even if $B_{t}^{F}=0$ so that the average foreign share equals zero, a fiscal expansion will have no crowding-out effects if $d B_{t}^{F} / d B_{t}=1$.

${ }^{16}$ This concern is especially relevant given the positive correlation between economic conditions and foreign holdings of domestic assets in the data. For evidence of this correlation, see Broner et al. (2013) and, for the case of public
} 
a positive correlation between effectiveness of expansions and ex-post foreign share can be due to reverse causality. Thus, we need an ex-ante measure of foreign share that is determined prior to the realization of the fiscal shock.

As it turns out, the ex-ante average foreign share $B_{t-1}^{F} / B_{t-1}$ is both directly observable and a very good proxy for the marginal foreign share. To see this, we run the following regression,

$$
\Delta B_{t}^{F}=\beta_{1}+\beta_{2} \cdot \Delta B_{t}+\beta_{3} \cdot X_{t-1}+\beta_{4} \cdot X_{t-1} \cdot \Delta B_{t}+v_{t}
$$

where $X_{t-1}=B_{t-1}^{F} / B_{t-1}$ denotes the average foreign share, $\Delta B_{t}^{F}=B_{t}^{F}-B_{t-1}^{F}$, and $\Delta B_{t}=$ $B_{t}-B_{t-1}$. The regression results are in Table 2, both for the U.S. and for the cross-section of OECD economies we analyze in Section 6. The table shows that the estimated coefficient on the interaction $X_{t-1} \cdot \Delta B_{t}$ is statistically significant and close to one. This means that the ex-ante average foreign share is indeed a good proxy for the marginal foreign share. Given this result, from now on whenever we speak of the foreign share we will refer to the ex-ante average foreign share, understanding that it is a proxy for the (unobserved) marginal foreign share. ${ }^{17}$

\section{[INSERT TABLE 2]}

\section{Empirical Methodology}

We now address the main objective of our paper and analyze how the distribution of public debt holdings affects the size of fiscal multipliers. Our empirical methodology follows the approach introduced by Ramey and Zubairy (2018), which conceptually consists of two steps. First, we use both fiscal shocks described above to instrument cumulative shocks to the fiscal variable of interest. ${ }^{18}$ Second, we estimate the effects of these instrumented fiscal shocks on cumulative output. The use of cumulative shocks and output allows for a direct interpretation of the IV effects as fiscal multipliers. In both steps we use Jordà's (2005) local projection method.

We begin by estimating a baseline specification to obtain unconditional multipliers. We then incorporate our measures of foreign share to estimate conditional multipliers.

debt in the context of the recent European crisis, Broner et al. (2014).

${ }^{17}$ Our result that the average foreign share is a good predictor of the marginal share is consistent with the results on average and marginal international portfolios in Kraay and Ventura (2000).

${ }^{18}$ As Ramey and Zubairy (2018) show, both instruments are necessary since, individually, they are not strong enough in the first stage. 


\subsection{Baseline specification}

We use both the defense news shocks and the residuals from the structural VAR to instrument for the cumulative sum of real government spending between $t+1$ and $t+h$, where $h$ is the horizon of the multiplier:

$$
\sum_{j=1}^{h} g_{t+j}=\alpha_{h}+\beta_{h}^{N} \cdot \epsilon_{t}^{N}+\beta_{h}^{V} \cdot \epsilon_{t}^{V}+\phi_{h}^{1}(L) \cdot Z_{t-1}+v_{t, h}
$$

where $\epsilon_{t}^{N}$ and $\epsilon_{t}^{V}$ are the two fiscal shocks and $Z_{t-1}$ is a vector of controls that includes lags of GDP and of both fiscal shocks. Since our data is quarterly, we also include seasonal dummies. Finally, we scale all variables by potential GDP, computed as HP-filtered real GDP. ${ }^{19}$

This allows us to obtain an instrumented measure of the cumulative sum of government spending,

$$
G_{t, h} \equiv \alpha_{h}+\beta_{h}^{N} \cdot \epsilon_{t}^{N}+\beta_{h}^{V} \cdot \epsilon_{t}^{V}+\phi_{h}^{1}(L) \cdot Z_{t-1}
$$

Finally, we regress the cumulative sum of real output between $t+1$ and $t+h$ on $G_{t, h}$ :

$$
\sum_{j=1}^{h} y_{t+j}=\alpha_{h}+\beta_{h}^{G} \cdot G_{t, h}+\phi_{h}^{G}(L) \cdot Z_{t-1}+v_{t, h},
$$

where the multiplier at horizon $h$ is given by

$$
m_{h} \equiv \beta_{h}^{G}
$$

i.e., $m_{h}$ measures the derivative of the cumulative change in output during the $h$ periods following a fiscal shock, with respect to the same-period cumulative change in government spending. In other words, the cumulative multiplier at horizon $h$ is defined as the integral of the output response over $h$ periods divided by the integral of government spending over the same $h$ periods following the initial shock. ${ }^{20}$

\subsection{Foreign share of public debt}

To assess how public debt holdings affect the size of fiscal multipliers, we add an interaction term between the instrumented fiscal shock and the foreign share. As we have already commented,

\footnotetext{
${ }^{19}$ We set the $\lambda$-parameter in the HP filter to 25600 . This leads to a similar series for potential GDP as the 6th degree polynomial method employed by Ramey and Zubairy (2018). Our results are unaffected by the choice of method used to estimate potential output.

${ }^{20}$ See also Mountford and Uhlig (2009), Uhlig (2010), and Fisher and Peters (2010).
} 
the foreign share is in turn proxied through the lag of the average foreign share, which is a good predictor of the marginal share. Formally, the foreign share $X_{t-1}$ is defined as

$$
X_{t-1}=\frac{D_{t-1}^{F}}{D_{t-1}}
$$

where $D_{t-1}$ is the total stock of public debt and $D_{t-1}^{F}$ is public debt held by foreigners.

Formally, the first-stage regressions are now

$$
\begin{gathered}
\sum_{j=1}^{h} g_{t+j}=\alpha_{h}+\beta_{h}^{N} \cdot \epsilon_{t}^{N}+\beta_{h}^{N X} \cdot \epsilon_{t}^{N} \cdot X_{t-1}+\beta_{h}^{V} \cdot \epsilon_{t}^{V}+\beta_{h}^{V X} \cdot \epsilon_{t}^{V} \cdot X_{t-1}+ \\
\beta_{h}^{X} \cdot X_{t-1}+\phi_{h}^{G}(L) \cdot Z_{t-1}+\phi_{h}^{G X}(L) \cdot Z_{t-1} \cdot X_{t-1}+v_{t, h}, \\
\sum_{j=1}^{h} g_{t+j} \cdot X_{t-1}=\alpha_{h}^{I}+\beta_{h}^{I N} \cdot \epsilon_{t}^{N}+\beta_{h}^{I N X} \cdot \epsilon_{t}^{N} \cdot X_{t-1}+\beta_{h}^{I V} \cdot \epsilon_{t}^{V}+\beta_{h}^{I V X} \cdot \epsilon_{t}^{V} \cdot X_{t-1}+ \\
\beta_{h}^{I X} \cdot X_{t-1}+\phi_{h}^{I G}(L) \cdot Z_{t-1}+\phi_{h}^{I G X}(L) \cdot Z_{t-1} \cdot X_{t-1}+v_{t, h}^{I},
\end{gathered}
$$

since we need to estimate separately how the fiscal shocks and their interaction with foreign share affect the cumulative sum of government spending and its interaction with foreign share. ${ }^{21}$ The instrumented variables are now

$$
\begin{aligned}
G_{t, h} \equiv & \alpha_{h}+\beta_{h}^{N} \cdot \epsilon_{t}^{N}+\beta_{h}^{N X} \cdot \epsilon_{t}^{N} \cdot X_{t-1}+\beta_{h}^{V} \cdot \epsilon_{t}^{V}+\beta_{h}^{V X} \cdot \epsilon_{t}^{V} \cdot X_{t-1}+ \\
& \beta_{h}^{X} \cdot X_{t-1}+\phi_{h}^{G}(L) \cdot Z_{t-1}+\phi_{h}^{G X}(L) \cdot Z_{t-1} \cdot X_{t-1}, \\
G X_{t, h} \equiv & \alpha_{h}^{I}+\beta_{h}^{I N} \cdot \epsilon_{t}^{N}+\beta_{h}^{I N X} \cdot \epsilon_{t}^{N} \cdot X_{t-1}+\beta_{h}^{I V} \cdot \epsilon_{t}^{V}+\beta_{h}^{I V X} \cdot \epsilon_{t}^{V} \cdot X_{t-1}+ \\
& \beta_{h}^{I X} \cdot X_{t-1}+\phi_{h}^{I G}(L) \cdot Z_{t-1}+\phi_{h}^{I G X}(L) \cdot Z_{t-1} \cdot X_{t-1} .
\end{aligned}
$$

Finally, we regress the cumulative sum of real output between $t+1$ and $t+h$ on $G_{t, h}$ and $G X_{t, h}$ :

$$
\begin{aligned}
\sum_{j=1}^{h} y_{t+j}= & \alpha_{h}^{F}+\beta_{h}^{G} \cdot G_{t, h}+\beta_{h}^{G X} \cdot G X_{t, h}+\beta_{h}^{F X} \cdot X_{t-1}+ \\
& \phi_{h}^{F G}(L) \cdot Z_{t-1}+\phi_{h}^{F G X}(L) \cdot Z_{t-1} \cdot X_{t-1}+v_{t, h}^{F},
\end{aligned}
$$

\footnotetext{
${ }^{21}$ Differently from Ramey and Zubairy (2018), we use a continuous variable to separate amongst states.
} 
where the multiplier at horizon $h$ is now a function of foreign share and is given by

$$
m_{h}\left(X_{t-1}\right) \equiv \beta_{h}^{G}+\beta_{h}^{G X} \cdot X_{t-1}
$$

\section{Multipliers and the foreign share of public debt}

In this section, we run the regressions in Equations (16) and (23) and report the results. We first show that our baseline regressions replicate the results obtained in the literature. We then show how the size of fiscal multipliers depends on the foreign share. We have devoted a significant effort to evaluate the validity of our instruments. Throughout this section, however, we report only the second-stage results, i.e., the estimates of the multiplier. We relegate all first-stage results, which relate to the effect of fiscal shocks on actual spending, to Appendix B. There we also provide details of the instrument-relevancy tests we conducted.

\subsection{Baseline specification}

Table 3 and Figure 3 respectively show the regression results and the cumulative multipliers that emerge from our baseline regression. ${ }^{22}$ Table 3 reports the coefficients $\beta_{h}^{G}$ for $h \leq 8$ quarters, i.e. up to a two-year horizon, whereas Figure 3 plots the cumulative multipliers for $h \leq 16$ quarters, i.e., up to a four-year horizon. In all figures, we also plot the 90 -percent confidence bands.

The estimated multiplier is 0.9 for the first quarter before declining to 0.4 after two years. It is statistically significant at the $1 \%$ level for the first four quarters. These results are in line with the existing literature. Applying the same methodology to a longer time sample, Ramey and Zubairy (2018) also report a cumulative multiplier of 0.4 for a two-year horizon.

\section{[INSERT TABLE 3]}

[INSERT FIGURE 3]

\subsection{Foreign share of public debt}

We now turn to our main results on the role of the foreign share, which are obtained by running the regression in Equation (23). Table 4 reports the estimated coefficients $\beta_{h}^{G}$ and $\beta_{h}^{G X}$ for $h \leq 8$

\footnotetext{
${ }^{22}$ Due to the inherent serial correlation in the local projections approach, we use Newey-West standard errors throughout.
} 
quarters, i.e. up to a two-year horizon. The main result is that the interaction coefficient $\beta_{h}^{G X}$ is statistically significant at the $1 \%$ level for $h \leq 5$ quarters and at the $10 \%$ level for $h \leq 8$ quarters.

Figure 4 illustrates the corresponding cumulative multipliers $m_{h}\left(X_{t-1}\right)$ for $h \leq 16$ quarters, i.e. up to a four-year horizon. Now that the cumulative multipliers depend on the foreign share of public debt, the figure contains three panels. The first panel plots the cumulative multipliers for a low foreign share, which corresponds to the 10th percentile of foreign holdings in the sample $\left(X_{t-1} \%=\right.$ $3 \%$ ). These cumulative multipliers are statistically indistinguishable from zero at all horizons. The second panel plots the cumulative multiplier for a high foreign share, which corresponds to the 90th percentile of foreign holdings in the sample $\left(X_{t-1}=47 \%\right.$ of debt held by foreigners). These cumulative multipliers are statistically different from zero at all horizons. The third panel plots the difference between the cumulative multipliers for high and low foreign share. The panel illustrates the results of Table 4 and shows that the regime-dependent multipliers are statistically different from each other.

\section{[INSERT TABLE 4] [INSERT FIGURE 4]}

From an economic standpoint, the effect of the foreign share on the size of the fiscal multiplier is large. For a low foreign share, the point estimate of the multipliers fall relative to those in our baseline regression. As a result, we can say fairly confidently that they are smaller than one but not whether they are positive. For a high foreign share, instead, the point estimate of the multipliers rise relative to those in our baseline regression. Although the standard errors also increase we can say confidently that they are greater than one for $h \leq 7$ quarters. Given the observed growth of foreign share throughout the sample, our results point to a significant increase in the fiscal multiplier over time. Figure 5 shows that this is indeed the case.

\section{[INSERT FIGURE 5]}

To make sure that our results are not driven by the recent global financial crisis, we repeat our exercise using data only up to $2006 .^{23}$ Figure 6, which replicates Figure 4 for this subsample, show that our results remain largely unaffected.

\section{[INSERT FIGURE 6]}

\footnotetext{
${ }^{23}$ Ramey and Zubairy (2018) emphasize the need for sufficiently long samples to generate informative estimates of state-dependent multipliers. To ensure our subsample is useful, we conducted the same instrument relevancy tests as for the full sample (see Appendix B). Our pre-crisis subsample passes these tests and is therefore suitable for use.
} 


\subsection{Other macroeconomic variables}

Our findings show that the foreign share of public debt holdings has a large effect on the size of the fiscal multiplier. But why is this the case? In the simple model of Section 3, the underlying narrative was that - relative to the case of a low foreign share - fiscal expansions lead to capital inflows and higher investment when the foreign share is high. To see whether this is consistent with the empirical evidence, we analyze next how different macroeconomic variables react to fiscal shocks. In particular, we run different versions of the regression in Equation (23) that alternatively use consumption, investment, and the current account instead of output as the dependent variable. The resulting cumulative multipliers are respectively depicted in panels (a), (b), and (c) of Figure 7 , which plot these multipliers under a low and a high foreign share, as well as the difference between the two.

\section{[INSERT FIGURE 7 (7a, 7b, 7c)]}

Taken jointly, these figures are consistent with the narrative outlined in the model. Panel (a) shows that, although the point estimates of the cumulative multipliers of consumption are higher when the foreign share is high, they are still small in absolute terms ( 0.5 or lower). Moreover, the difference between both multipliers is not statistically significant at the $10 \%$ level, as can be seen from the third panel in the figure. Panel (b) shows that the situation is different for investment. Here, the cumulative multiplier is greater when the foreign share is high: on impact, the investment multiplier is approximately 1.8 for a high foreign share, but it is -0.4 for a low foreign share. The difference between both is statistically significant for $h \leq 4$ quarters. Finally, panel (c) shows that foreign debt holdings also appear to matter for the current account. Specifically, the figure shows that the estimated cumulative multiplier on the current account is basically zero when the foreign share is low, but it is negative when the foreign share is high.

All in all, the three panels of Figure 7 suggest that the higher output multiplier when foreign share is high is associated with higher levels of investment and capital inflows. This is consistent with the narrative laid out in the model of Section 3. Namely, when foreigners are willing to purchase domestic government debt, fiscal expansions can be financed by capital inflows and they do not crowd out domestic investment. 


\subsection{Is it really the foreign share of public debt?}

So far we have only considered the foreign share as a possible determinant of the size of the fiscal multiplier. How can we know whether it is actually the foreign share or other, correlated variables, that drive our results?

We address this question by performing a "race" between alternative explanations. We amend Equations (19)-(23) to alternatively include a time trend, trade openness, and total public debt as competing explanatory variables. In each case, we keep the foreign share and its interactions and add the competing explanatory variable in a symmetric way, i.e. also in levels and interacted with the fiscal shocks.

The results are illustrated in panels (a), (b), and (c) of Figure 8. As these figures show, the introduction of these additional variables does not significantly alter our findings: the cumulative fiscal multipliers appear to be closely associated with the foreign share, and the difference between the multipliers at high and low levels of foreign shares remains positive and statistically significant.

[INSERT FIGURE $8(8 \mathrm{a}, 8 \mathrm{~b}, 8 \mathrm{c})$ ]

\section{Multipliers around the World}

To assess the generality of our results for the US, in this section we carry out a similar analysis for a cross-section of advanced economies. The substantial heterogeneity of foreign public debt holdings across countries and time in our sample provides a stern test of the importance of foreign public debt holdings on the size of fiscal multipliers. We follow Guajardo et al. (2014) and Jordà and Taylor (2016) in using the cyclically-adjusted primary deficit as the fiscal variable (instead of government consumption) and in instrumenting it using announcements of fiscal consolidations applying the narrative approach. In other respects, the empirical methodology follows Ramey and Zubairy (2018).

We start by describing the data on foreign share of public debt holdings and fiscal shocks. We then explain how we extend the methodology of the previous sections to a panel context. Finally, we discuss the empirical results. As in the case of the US, we relegate all first-stage results to Appendix D. 


\subsection{Data}

We construct a novel dataset of public debt holdings for a large set of advanced economies. We view the construction of this dataset as an additional contribution of this paper. For shocks to fiscal balances, we use the data on fiscal consolidations by Guajardo et al. (2014) and the extension by Valles and Kataryniuk (2015). For a detailed description of the sources used to construct the dataset, see Appendix C.

\subsubsection{Foreign share of public debt}

The data is annual and covers 17 countries. The start of the sample varies by country, ranging from the late 1970s to the early 1990s. The sample ends in 2014. The countries covered are: Australia, Austria, Belgium, Canada, Denmark, Finland, France, Germany, Ireland, Italy, Japan, the Netherlands, Portugal, Spain, Sweden, the United Kingdom and the United States. It significantly expands the time coverage of the dataset constructed by Arslanalp and Tsuda (2012), who provide quarterly data for 24 advanced economies, but starting in 2004.

Since we are interested in fiscal policy at the consolidated government level, our data is for General Government Debt. To avoid distortions due to valuation effects, we measure debt at face value. $^{24}$ We rely on multiple domestic and international sources to construct this dataset. These include the Balance of Payments (Financial Accounts, International Investment Positions), Monetary Surveys and data provided to us directly by our sample countries' Central Banks, Ministries of Finance and Statistical Offices.

Figure 9 shows our raw data by plotting domestic and foreign holdings of public debt, normalized by GDP. In the figure, each observation corresponds to a given country in a given year. The figure illustrates that in our sample there is a large variation both in the levels of debt and in their allocation between domestic and foreign holders. The data ranges from debt levels below $20 \%$ to above $200 \%$ of GDP.

Figure 10 shows the evolution of the foreign share for all countries in our sample. A first striking feature is that the foreign share has increased over time in most countries in our sample. This increase has not been uniform over time though. For example, the countries in the euro periphery saw a reduction in foreign share after the onset of the sovereign debt crisis in $2009 .^{25}$

\footnotetext{
${ }^{24}$ See Brutti and Saure (2015) for a discussion of potential biases due to price effects.

${ }^{25}$ For a detailed account of the dynamics of foreign share of public debt during the European debt crisis see Broner et al. (2014).
} 
Figure 10 also shows that there is heterogeneity in foreign share across countries. At one extreme, Japan has displayed close to $0 \%$ foreign share throughout the sample. At the other extreme, several small countries in the euro area, such as Austria and Finland, have displayed a foreign share above $75 \%$ at some point in our sample.

\section{[INSERT FIGURE 9] \\ [INSERT FIGURE 10]}

\subsubsection{Fiscal shocks}

For shocks to fiscal balances, we follow Guajardo et al. (2014) and the extension by Valles and Kataryniuk (2015). These series are constructed by analyzing contemporaneous policy documents to identify discretionary fiscal consolidations, i.e. changes in tax rates and government spending that are not motivated by current or prospective economic conditions. The magnitudes of the shocks reflect the expected future budgetary impact of the consolidations.

Using this narrative approach, they identify 230 fiscal consolidations for our sample of 17 OECD economies between 1978 and 2014. The average budgetary impact of these consolidations is $-1.1 \%$ of GDP, ranging from 0.8\% of GDP (Portugal, 2003) to -6.0\% of GDP (Portugal, 2012). A positive budgetary impact reflects the expiration of temporary consolidation measures, e.g. a temporary reduction in spending that expires. We show the resulting narrative fiscal shocks in Figure 11.

\section{[INSERT FIGURE 11]}

\subsection{Empirical Methodology}

The empirical specification for the cross-section of advanced economies is similar to the one for the U.S. There are a few differences: (i) the fiscal variable is the cyclically-adjusted primary deficit instead of government expenditure; (ii) the instrument is the narrative measure of fiscal consolidations instead of announcement of defense spending and VAR residuals; (iii) the data is annual instead of quarterly; (iv) the regressions are in panels with country and time fixed effects instead of time series; and (v) following Guajardo et al. (2014) and Jordà and Taylor (2016) we use the contemporaneous instrument instead of lagging it one period given that the data is annual. 


\subsection{Results}

The baseline results are reported in Table 5 and Figure 12. They both show the coefficients $\beta_{h}^{G}$ for $h \leq 4$ years. In the figure we also plot the 90-percent confidence bands. The estimated cumulative multipliers are around 0.5 and statistically significant for horizons of up to 3 years. This is similar to the multipliers we had found for government spending shocks in our baseline results for the U.S. ${ }^{26}$

[INSERT TABLE 5]

[INSERT FIGURE 12]

The results on the role of the foreign share are reported in Table 6 and Figure 13 for $h \leq 4$ years.

Table 6 shows the coefficients $\beta_{h}^{G}$ and $\beta_{h}^{G X}$. The main result is that the interaction coefficient $\beta_{h}^{G X}$ is statistically significant at the $5 \%$ level for $2 \leq h \leq 4$ years.

Figure 13 illustrates the corresponding cumulative multipliers $m_{h}\left(X_{t}\right)$. Now that the cumulative multipliers depend on the foreign share of public debt holdings, the figure contains three panels. The first panel plots the cumulative multipliers for a low foreign share, which corresponds to the 10th percentile of foreign holdings in the sample $\left(X_{t} \%=6 \%\right)$. These cumulative multipliers are statistically indistinguishable from zero at all horizons. The second panel plots the cumulative multiplier for a high foreign share, which corresponds to the 90th percentile of foreign holdings in the sample $\left(X_{t}=66 \%\right.$ of debt held by foreigners). These cumulative multipliers are statistically different from zero at all horizons and the point estimates are above one. The third panel plots the difference between the cumulative multipliers for high and low foreign share. The panel illustrates the results of Table 6 and shows that the regime-dependent multipliers are statistically different from each other.

\section{[INSERT TABLE 6]}

\section{[INSERT FIGURE 13]}

As in the U.S. results, the effect of the foreign share on the size of the fiscal multiplier is large. For low foreign share, we can say fairly confidently that the fiscal multipliers are smaller than one and might even be zero. For high foreign share, instead, the point estimates are above one,

\footnotetext{
${ }^{26}$ Note that these results cannot be directly compared to those in Guajardo et al. (2014) and Jordà and Taylor (2016) since their methodology provides dynamic output responses as opposed to multipliers.
} 
although given the high standard errors we can reject that they are zero but not that they are one. As examples, these results suggest that in a country with low foreign share like Japan $\left(X_{t}=8 \%\right)$ the multiplier is essentially zero while in a country with high foreign share like Ireland $\left(X_{t}=64 \%\right)$ the multiplier is likely above one.

\section{Discussion and concluding remarks}

This paper has argued that there is a natural connection between fiscal multipliers and the foreign holdings of public debt. In particular, the effects of fiscal expansions on economic activity are stronger when they are financed with foreign resources. Empirically, the estimated size of fiscal multipliers is increasing in the share of public debt that is in the hands of foreigners. This result holds both for the United States during the postwar period, and for a panel of advanced (OECD) economies over the last few decades. In both cases, the estimated multiplier is larger than one in periods and countries with a high foreign share of public debt holdings, and is smaller than one in periods and countries with a low foreign share.

These findings have important implications for the way we think about fiscal policy in open economies. First, they challenge the conventional Mundell-Fleming view by highlighting one channel through which openness raises fiscal multipliers. Namely, capital inflows help finance fiscal expansions thereby minimizing their crowding-out effects on domestic investment. In a similar vein, they challenge the common perception that, by raising demand for foreign goods, fiscal expansions by any one country generate positive spillovers for other countries. Our findings instead point to a potentially negative spillover: to the extent that fiscal expansions are financed via foreign borrowing, their crowding-out effects are exported and consumption and investment are reduced elsewhere. More broadly, they suggest that the effects of fiscal expansions in a globalized world depend crucially on how they are financed.

\section{References}

[1] Acconcia, A., Corsetti, G., and Simonelli, S. (2014). "Mafia and Public Spending: Evidence on the Fiscal Multiplier from a Quasi-experiment", American Economic Review, 104(7): 21852209 . 
[2] Alesina, A. and Ardagna, S. (2013). "The Design of Fiscal Adjustments", Tax Policy and the Economy, 27(1): 19-68.

[3] Arslanalp, S. and Takahiro, T. (2012). "Tracking Global Demand for Advanced Economy Sovereign Debt", IMF WP/12/284.

[4] Acharya, V., Drechsler, I., and Schnabl, P. (2014). "A pyrrhic victory? Bank bailouts and sovereign credit risk", Journal of Finance, 69(6): 2689-2739.

[5] Auerbach, A. J. and Gorodnichenko, Y. (2012). "Measuring the output responses to fiscal policy", American Economic Journal: Economic Policy, 4(2): 1-27.

[6] Barro, R. J. (1974). "Are government bonds net wealth?", Journal of Political Economy, 82(6): 1095-1117.

[7] Bernanke, B., Reinhart, V., and Sack, B. (2004). "Monetary Policy Alternatives at the Zero Bound: An Empirical Assessment", Brooking Papers on Economic Activity, 2: 1-100.

[8] Blanchard, O. J. and Leigh, D. (2013). "Growth Forecast Errors and Fiscal Multipliers", American Economic Review: Papers and Proceedings, 103(3): 117-120.

[9] Blanchard, O. J. and Perotti, R. (2002). "An empirical characterization of the dynamic effects of changes in government spending and taxes on output", Quarterly Journal of Economics, 117(4): 1329-68.

[10] Broner, F., Didier, T., Erce, A., and Schmukler, S. (2013). "Gross Capital Flows: Dynamics and Crises", Journal of Monetary Economics, 60(1): 113-133.

[11] Broner, F., Erce, A., Martin, A., and Ventura, J. (2014). "Sovereign Debt Markets in Turbulent Times: Creditor Discrimination and Crowding Out", Journal of Monetary Economics, 61: 114142.

[12] Broner, F. and Ventura, J. (2014). "Globalization and Risk Sharing", Review of Economic Studies, 78(1): 49-82.

[13] Brutti F. and Saure, P. (2015). "Transmission of sovereign risk in the Euro crisis", Journal of International Economics, 97(2): 231-248. 
[14] Brutti F. and Saure, P. (2016). "Repatriation of debt in the euro crisis", Journal of the European Economic Association, 14(1): 145-174.

[15] Caballero, R., Farhi, E., and Gourinchas, P.O. (2016). "Safe Asset Scarcity and Aggregate Demand", American Economic Review Papers and Proceedings, 106(5): 513-518.

[16] Cacciatore M., and N. Traum (2018). "Trade Flows and Fiscal Multipliers", Mimeo.

[17] Chari, V. V., Dovis, A., and Kehoe, P. J. (2016). "On the Optimality of Financial Repression", Research Department Staff Report 1000, Federal Reserve Bank of Minneapolis.

[18] Christiano, L., Eichenbaum, M., and Rebelo, S. (2011). "When is the Government Spending Multiplier Large?", Journal of Political Economy, 119(1): 78-121.

[19] Corsetti, G., Meier, A., and Muller, G. J. (2012). "What determines government spending multipliers?", Economic Policy, 27(72): 521-565.

[20] Diamond, D. (1965). "National debt in a neoclassical growth model", American Economic Review, 55: 1126-1150.

[21] Farhi, E. and Werning, I. (2012). "Fiscal Multipliers: Liquidity Traps and Currency Unions", Handbook of Macroeconomics, 2: 2417-2492.

[22] Fahri, E. and Tirole, J. (2018). "Deadly Embrace: Sovereign and Financial Balance Sheets Doom Loops", Review of Economic Studies, forthcoming.

[23] Fisher, J. D. M. and Peters, R. (2010). "Using Stock Returns to Identify Government Spending Shocks", Economic Journal, 120: 414-436.

[24] Gennaioli, N., Martin, A., and Rossi, S. (2014). "Sovereign default, domestic banks, and financial institutions", Journal of Finance, 69(2): 819-866.

[25] Guajardo, J., Leigh, D., and Pescatori, A. (2014). "Expansionary austerity? International evidence", Journal of the European Economic Association, 12(4): 949-968.

[26] Guembel, A. and Sussman, O. (2009). "Sovereign Debt without Default Penalties", Review of Economic Studies, 76(4): 1297-1320.

[27] Ilzetzki, E., Mendoza, E. G., and Vegh, C. A. (2013). "How big (small?) are fiscal multipliers?", Journal of Monetary Economics 60(2): 239-254. 
[28] Jorda, O. (2005). "Estimation and Inference of Impulse Responses by Local Projections", American Economic Review, 95(1): 161-182.

[29] Jorda, O. and Taylor, A. M. (2016). "The Time for Austerity: Estimating the Average Treatment Effect of Fiscal Policy", Economic Journal, 126(590): 219-255.

[30] Kataryniuk, I. and Valles, J. (2015). "Fiscal consolidation after the Great Recession: The role of composition", Banco de Espana Working Paper 1515.

[31] Kleibergen, F. and Paap, R. (2006). "Generalized reduced rank tests using the singular value decomposition", Journal of Econometrics, 133: 97-126.

[32] Kraay, A. and Ventura, J. (2000). "Current accounts in debtor and creditor countries", Quarterly Journal of Economics, 115(4): 1137-1166.

[33] Mertens, K. and Ravn, M. O. (2013). "The Dynamic Effects of Personal and Corporate Income Tax Changes in the United States", American Economic Review, 103(4): 1212-47.

[34] Miyamoto, W., Nguyen, T. L. and Sergeyev, D. (2018). "Government Spending Multipliers under the Zero Lower Bound: Evidence from Japan", American Economic Journal: Macroeconomics, 10(3): 247-277.

[35] Mountford, A. and Uhlig, H. (2009). "What are the effects of fiscal policy shocks?", Journal of Applied Econometrics, 24(6): 960-992.

[36] Olea, J. L. M. and Pflueger, C. (2013). "A robust test for weak instruments", Journal of Business and Economics Statistics, 31: 358-368.

[37] Priftis, R. and Zimic, S. (2015). "Sources of Borrowing and Fiscal Multipliers", in Fiscal Policy in the Great Recession, European University Insitute, Department of Economics.

[38] Priftis, R. and Zimic, S. (2018). "Sources of borrowing and fiscal multipliers", Bank of Canada Staff Working Paper 2018-32.

[39] Ramey, V. A. (2011a). "Can government purchases stimulate the economy?", Journal of Economic Literature, 49(3): 673-685.

[40] Ramey, V. A. (2011b). "Identifying government spending shocks: it's all in the timing", Quarterly Journal of Economics, 126(1): 1-50. 
[41] Ramey, V. A. (2016). "Macroeconomic shocks and their propagation", Handbook of Macroeconomics, 2: 71-162.

[42] Ramey, V. A. and Zubairy, S. (2018). "Government spending multipliers in good times and in bad: Evidence from US historical data", Journal of Political Economy, 126(2): 850-901.

[43] Reinhart, C. and Sbrancia, B. (2015). "The liquidation of government debt", Economic Policy, 30(82): 291-333.

[44] Sanderson, E. and Windmeijer, F. (2016). "A weak instrument F-test in linear IV models with multiple endogenous variables", Journal of Econometrics, 190(2): 212-221.

[45] Shen, W., Yang, S.C.S. and Zanna, L.F. (2018). "Government spending effects in low-income countries ", Journal of Development Economics, 133: 201-219.

[46] Sin J. (2016). "The Fiscal Multiplier in Small Open Economy: The Role of Liquidity Frictions", IMF Working Paper 16/138.

[47] Staiger, D. and Stock, J. H. (1997). "Instrumental variables regression with weak instruments", Econometrica, 65: 557-586.

[48] Stock, J. H. and Yogo, M. (2005). "Testing for weak instruments in linear IV regression", In: Andrews, D.W.K. and J.H. Stock (Eds.), Identification and Inference for Econometric Models, Essays in Honor of Thomas Rothenberg, Cambridge University Press, pp. 80-108.

[49] Uhlig, H. (2010). "Some Fiscal Calculus", American Economic Review, 100(2): 30-34.

[50] Warnock, F. E.and Warnock, V. C. (2009). "International capital flows and U.S. interest rates", Journal of International Money and Finance, 28(6): 903-919.

[51] Wu, T. (2005), The long-term interest rate conundrum: Not unraveled yet?," FRBSF Economic Letter, (29), April. 


\section{Figures and Tables}

FIGURE 1. Foreign share of U.S. public debt holdings

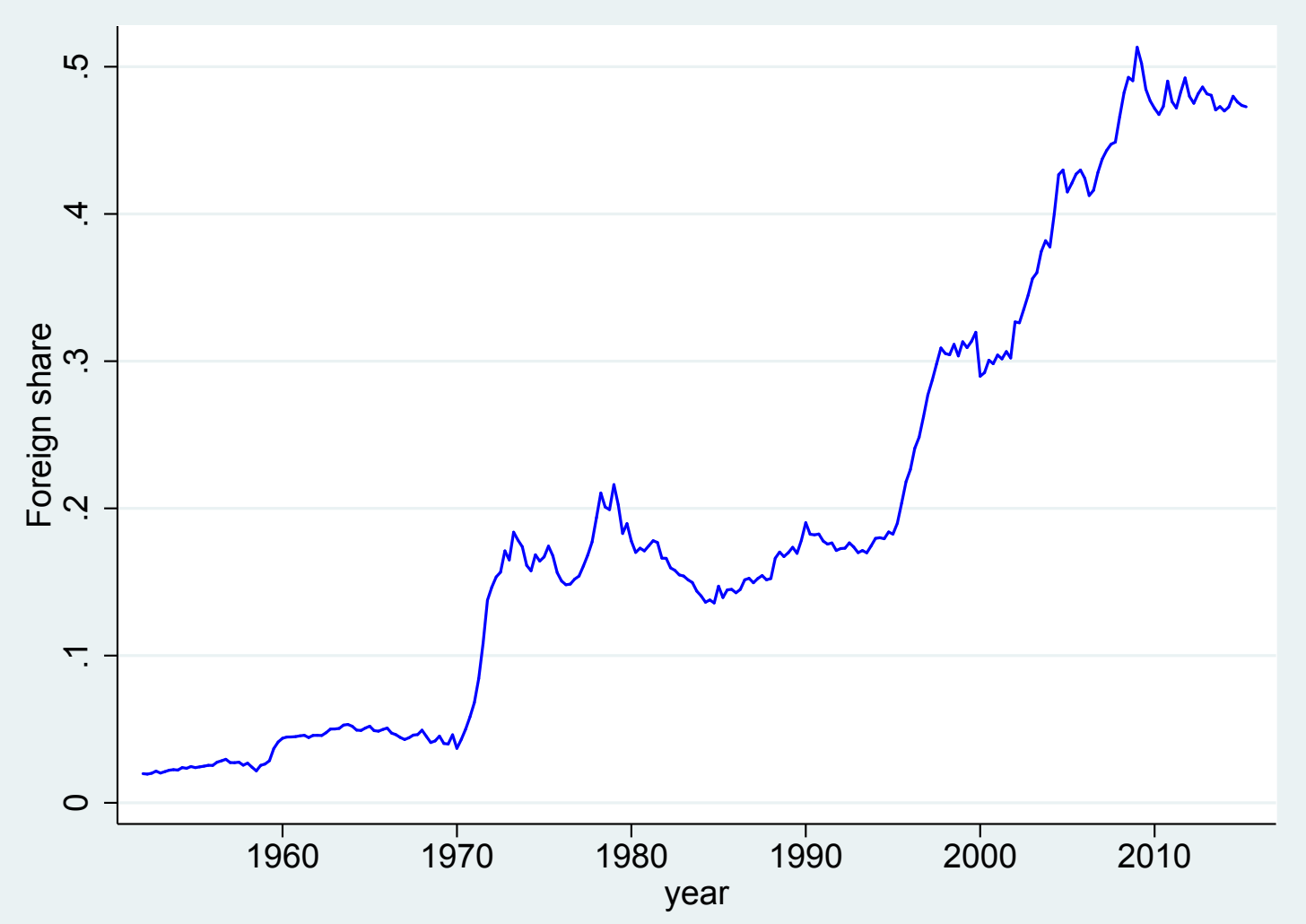

Notes: Foreign share is the rest of the world's holdings of U.S. federal government's treasury securities liabilities as a proportion of total U.S. federal government treasury securities liabilities. 


\section{FIGURE 2. Identifed U.S. fiscal shocks}

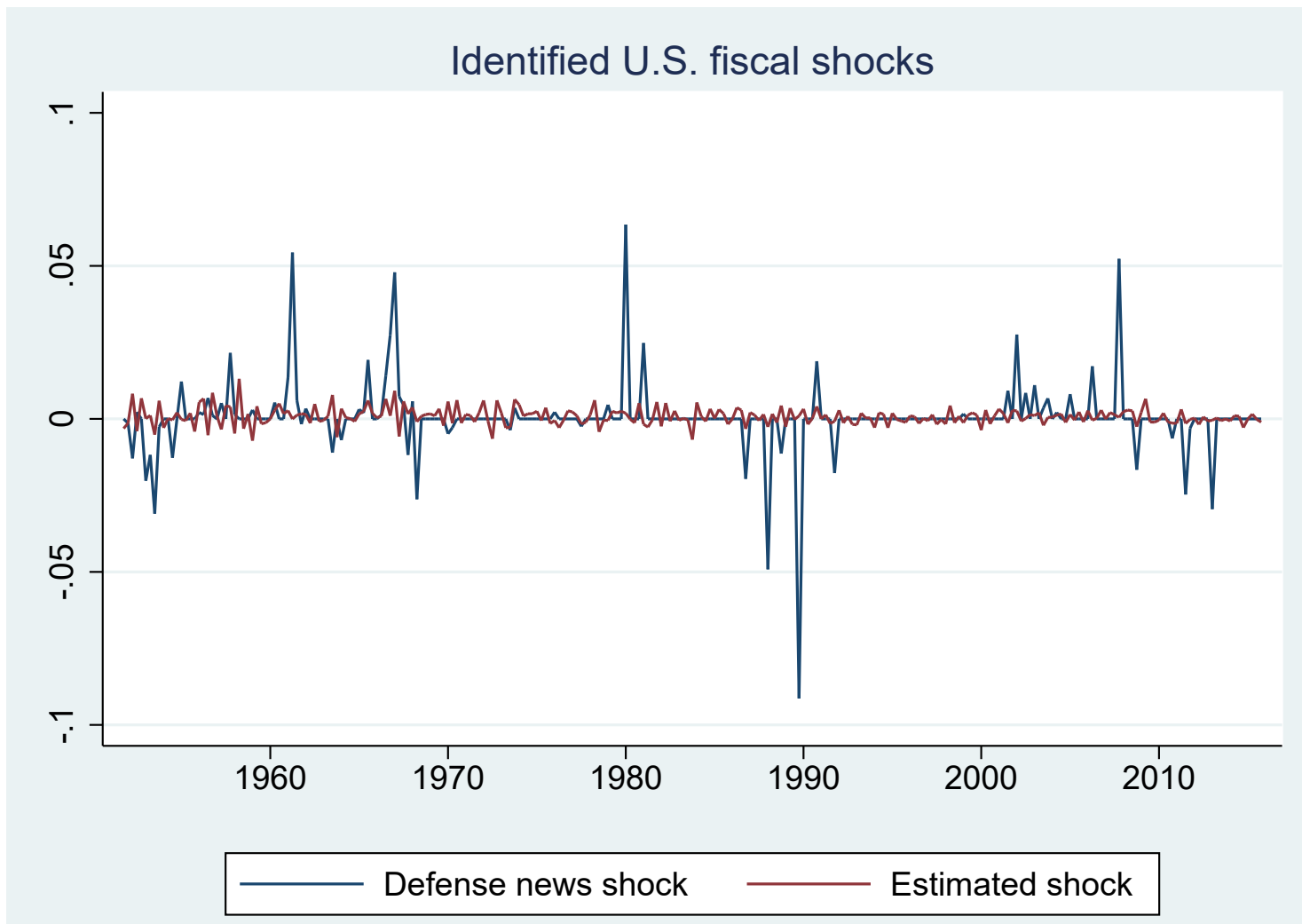

Notes: The defense news shocks are from Ramey and Zubairy (2018). The Blanchard-Perotti shocks are the residuals from our estimation of a structural VAR $a$ la Blanchard and Perotti (2002). Both shocks are normalized by potential GDP. 


\section{FIGURE 3. Baseline model: U.S. output multiplier}

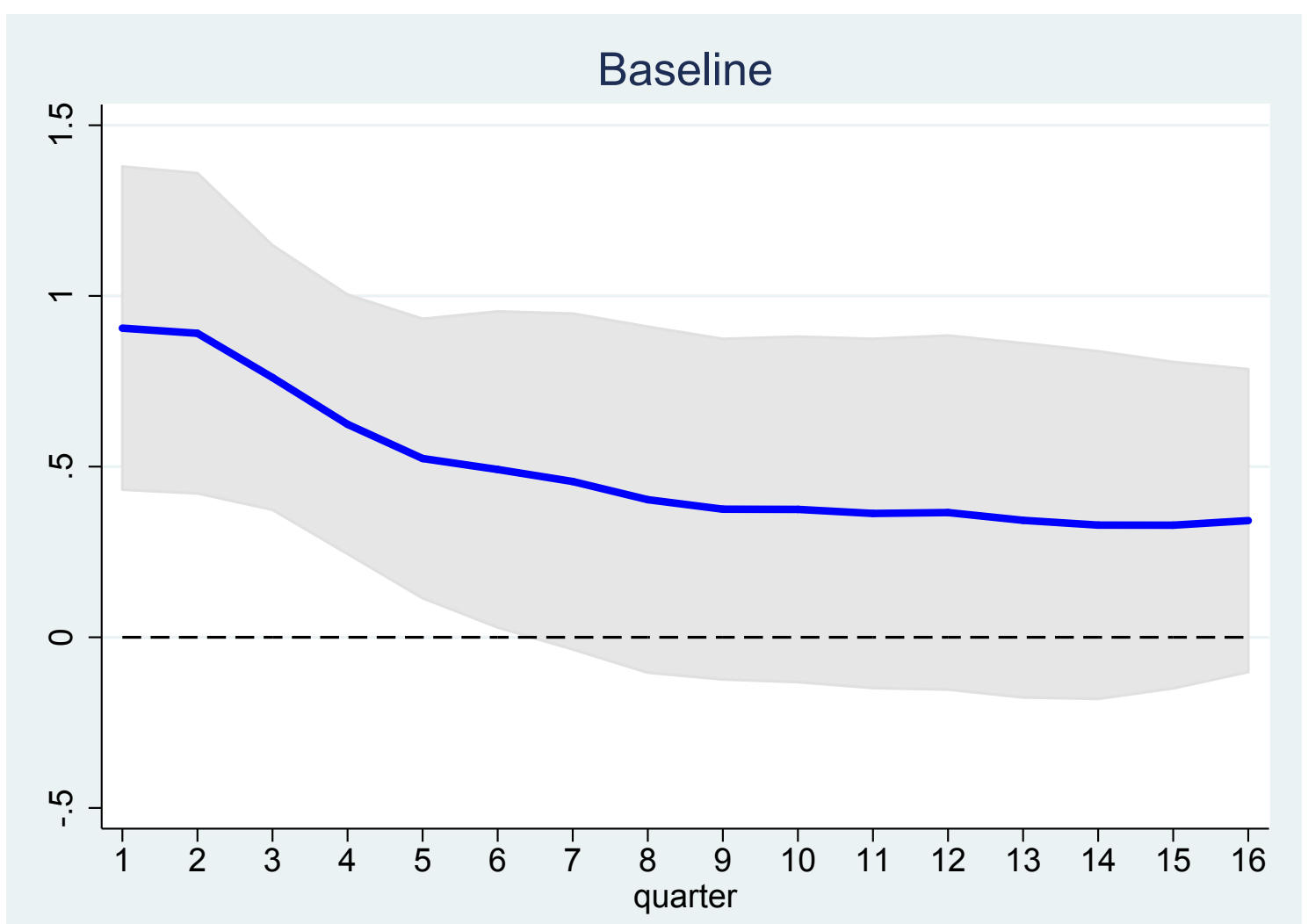

Notes: Cumulative GDP multiplier from a defense news shock equal to $1 \%$ of GDP. The shaded area represents the $90 \%$ confidence bands. 
FIGURE 4. Foreign share: U.S. output multiplier
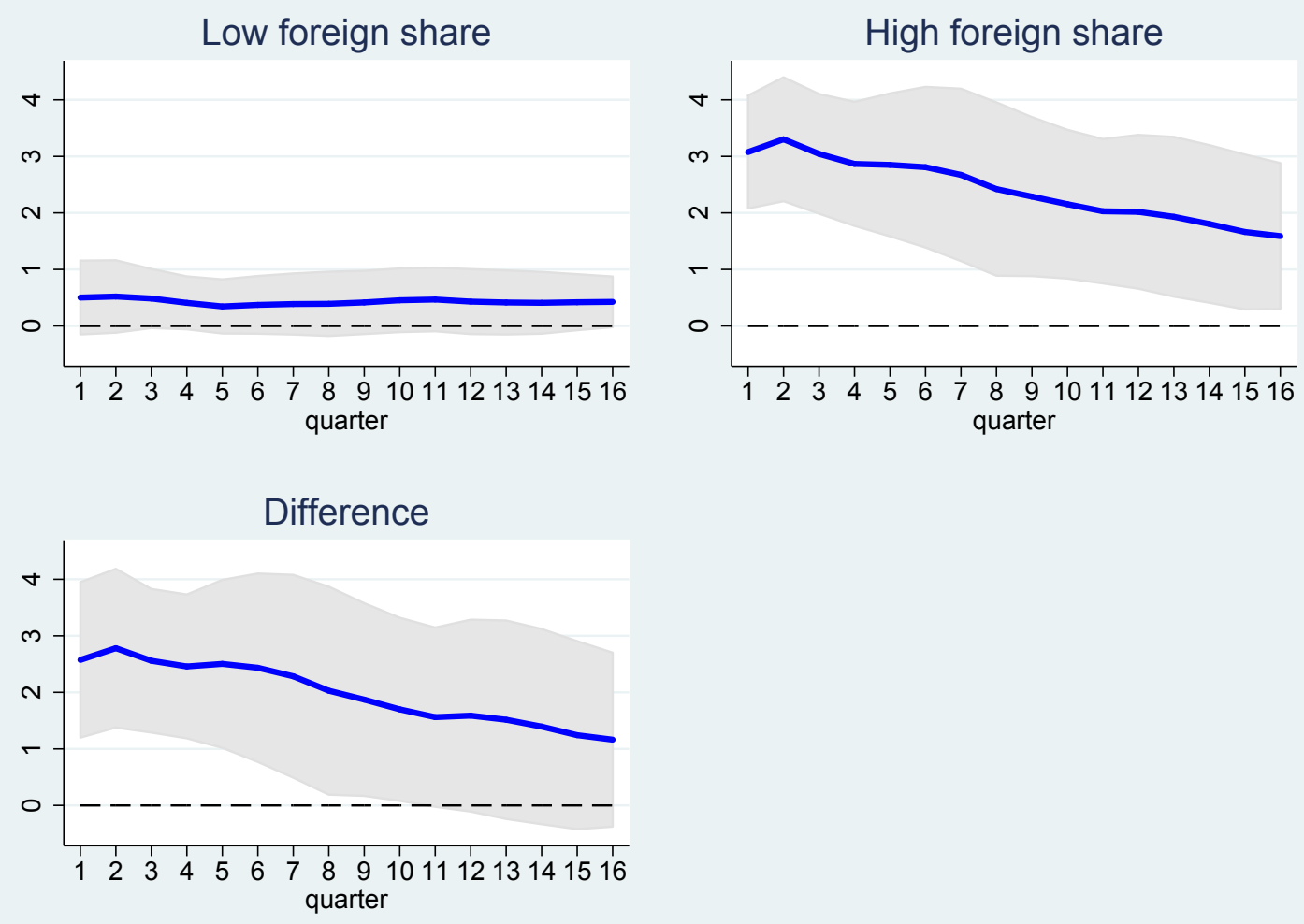

Notes: Cumulative GDP multipliers from a defense news shock equal to 1\% of GDP with low (10th percentile of foreign holdings in the sample) and high (90th percentile of foreign holdings in the sample) foreign share, and the difference between the two multipliers. The shaded area represents the $90 \%$ confidence bands. 
FIGURE 5. Effect on U.S. output of a government expenditure shock after 4 quarters

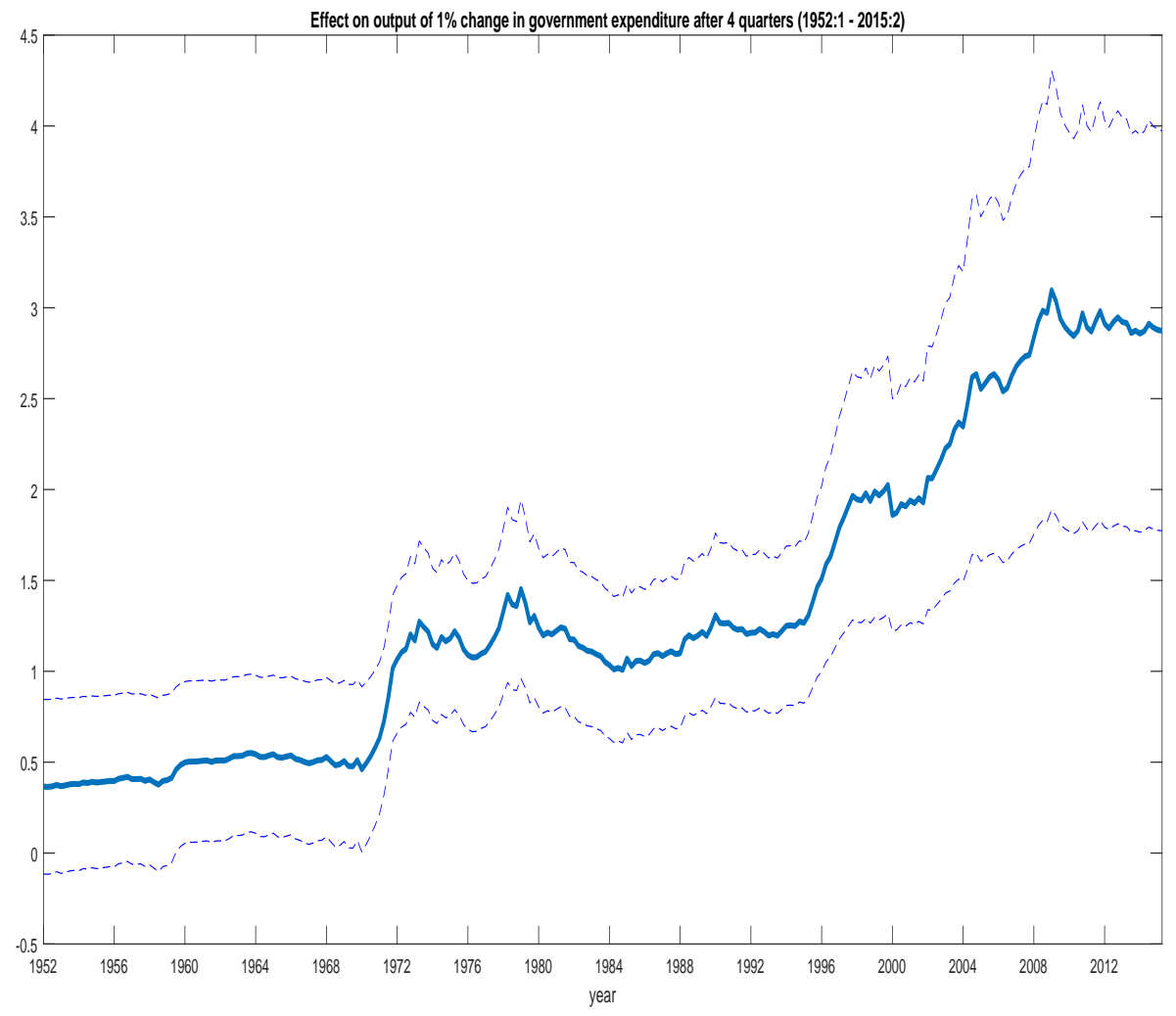

Notes: Foreign share-dependent cumulative multiplier after four periods from a defense news shock equal to $1 \%$ of GDP. The dashed lines represents the $90 \%$ confidence bands. 
FIGURE 6. Foreign share: pre-crisis U.S. output multiplier
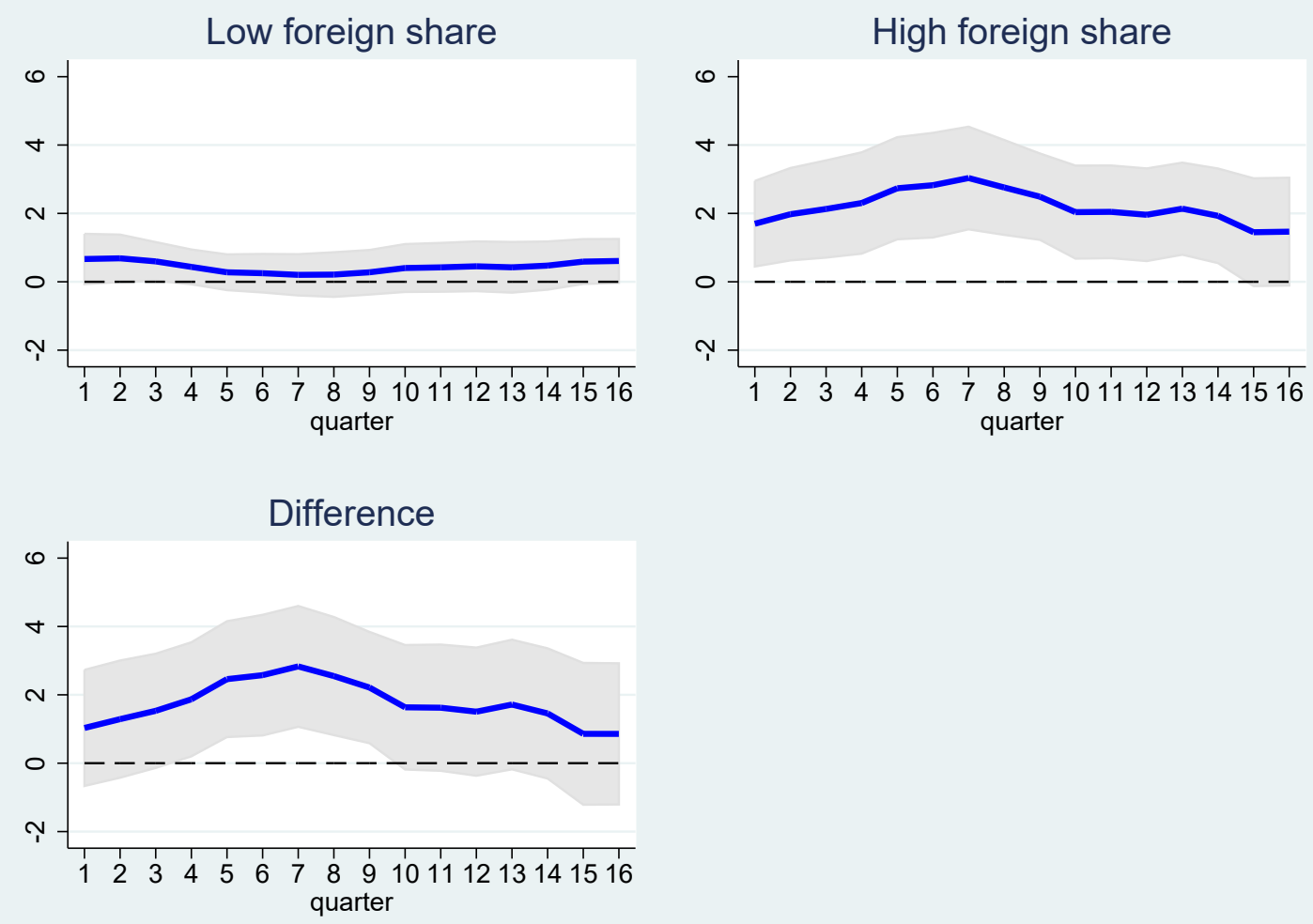

Notes: Pre-crisis period defined as up to and including 2006. Cumulative multipliers from a defense news shock equal to $1 \%$ of GDP for low (10th percentile of foreign holdings in the sample) and high (90th percentile of foreign holdings in the sample) foreign share, and the difference between the two multipliers. The shaded area represents the $90 \%$ confidence bands. 
FIGURE 7A. Foreign share: U.S. consumption multiplier
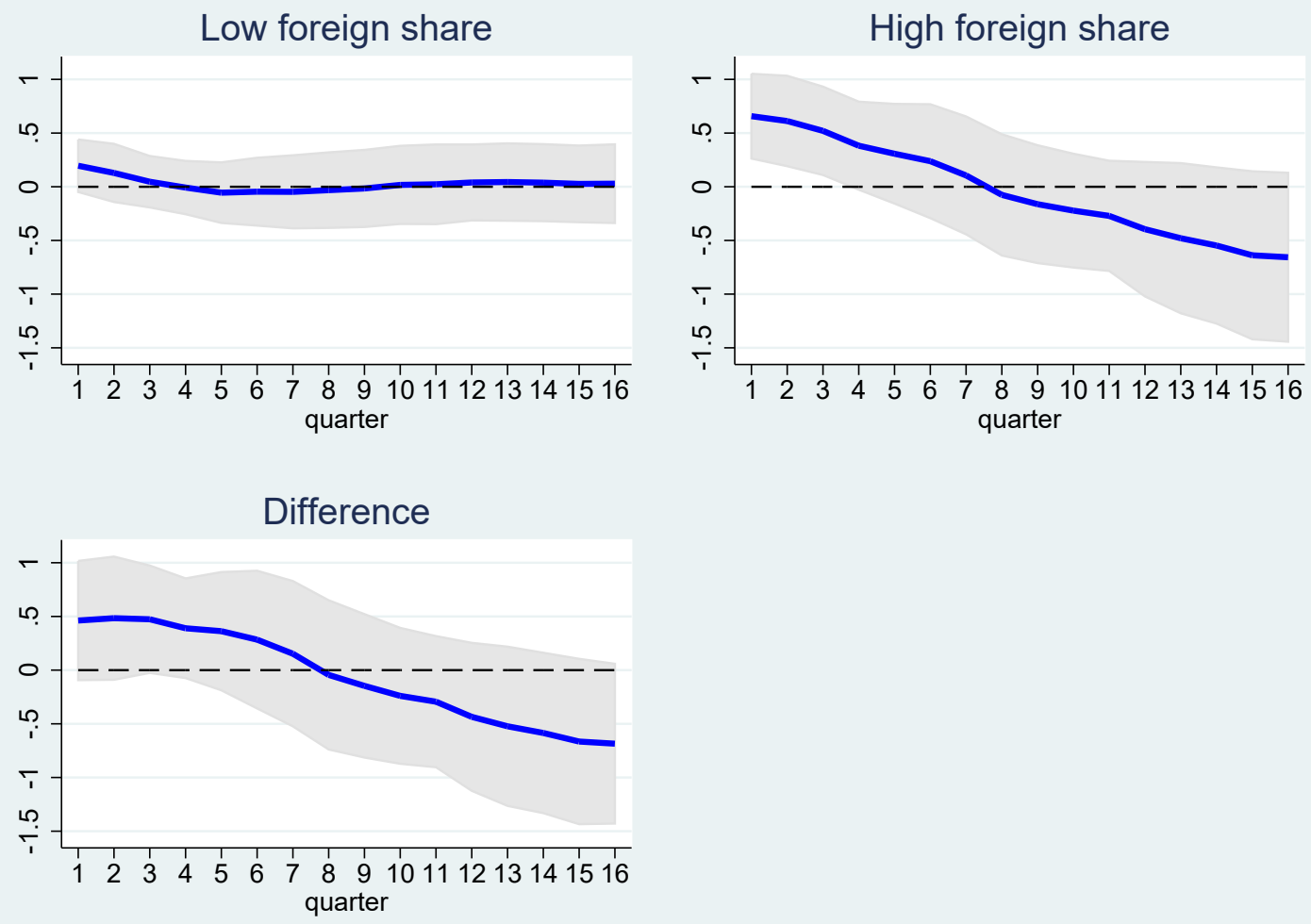

Notes: Cumulative consumption multipliers from a defense news shock equal to $1 \%$ of GDP for low (10th percentile of foreign holdings in the sample) and high (90th percentile of foreign holdings in the sample) foreign share, and the difference between the two multipliers. The shaded area represents the $90 \%$ confidence bands. 


\section{FIGURE 7B. Foreign share: U.S. investment multiplier}

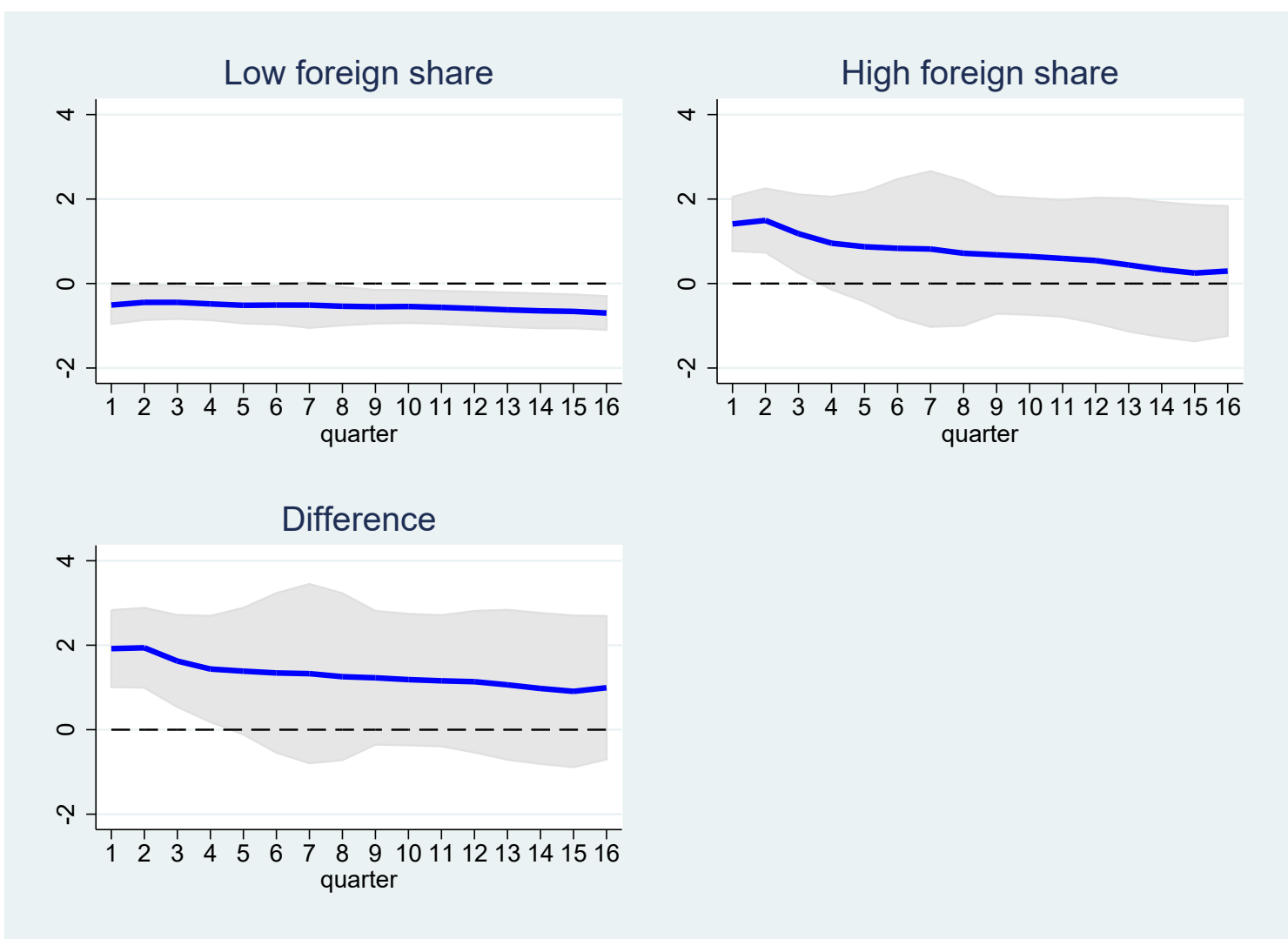

Notes: Cumulative investment multipliers from a defense news shock equal to 1\% of GDP for low (10th percentile of foreign holdings in the sample) and high (90th percentile of foreign holdings in the sample) foreign share, and the difference between the two multipliers. The shaded area represents the $90 \%$ confidence bands. 
FIGURE 7C. Foreign share: U.S. current account multiplier
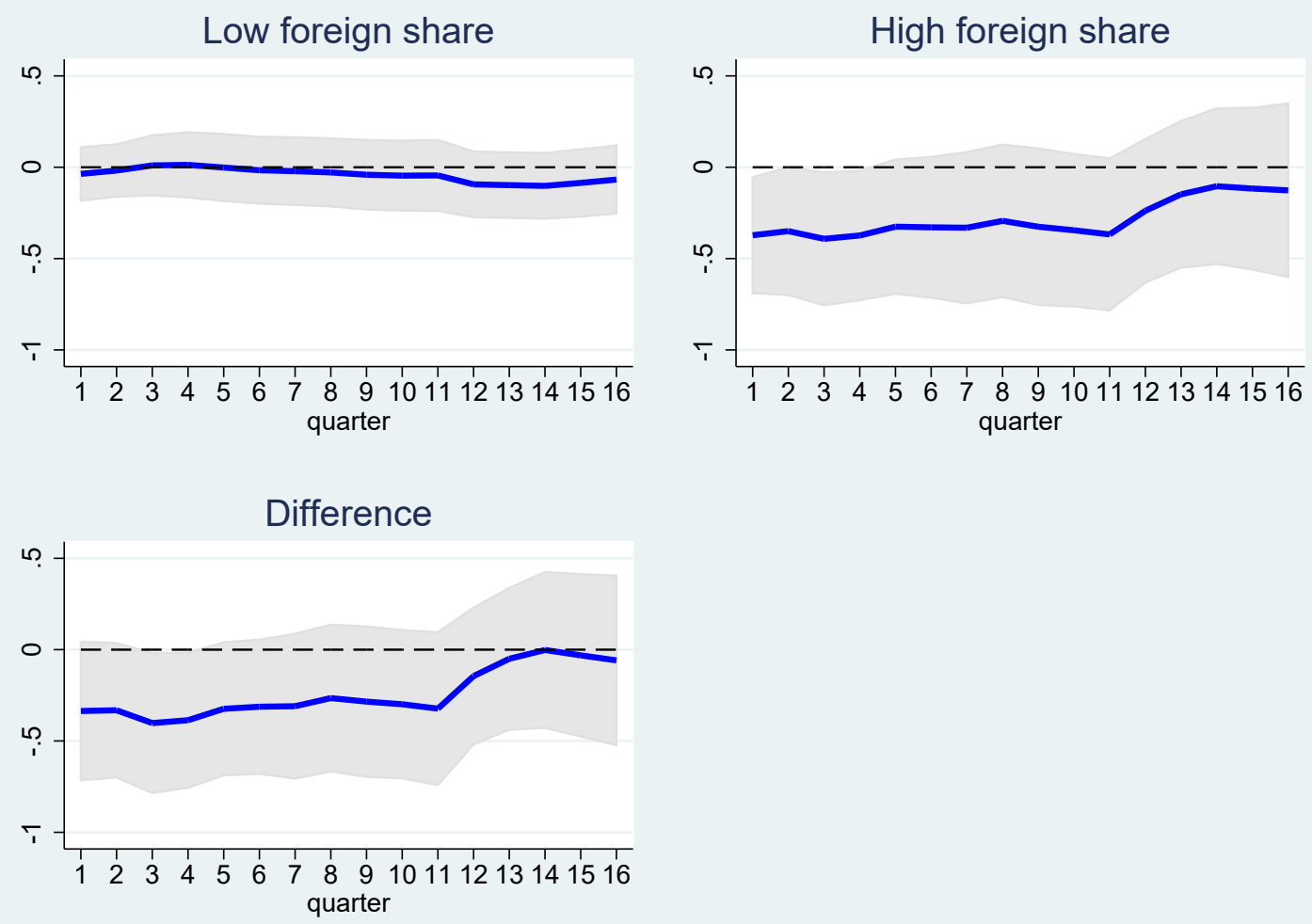

Notes: Cumulative current account multipliers from a defense news shock equal to 1\% of GDP for low (10th percentile of foreign holdings in the sample) and high (90th percentile of foreign holdings in the sample) foreign share, and the difference between the two multipliers. The shaded area represents the $90 \%$ confidence bands. 


\section{FIGURE 8A. Foreign share and time trend: U.S. output multiplier}
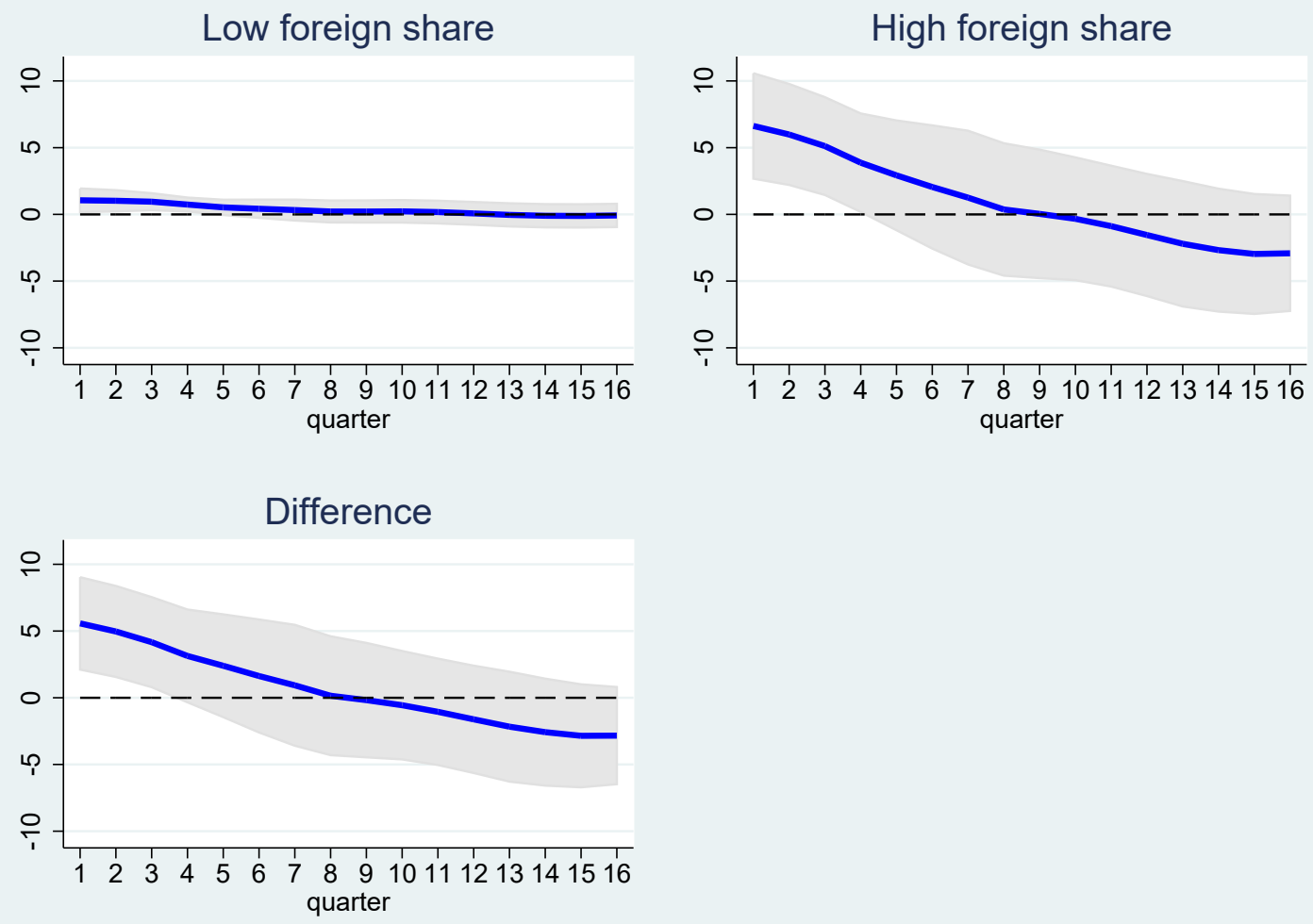

Notes: Cumulative GDP multipliers from a defense news shock equal to 1\% of GDP for low (10th percentile of foreign holdings in the sample) and high (90th percentile of foreign holdings in the sample) foreign share when a time trend is included as an alternative explanation, and the difference between the two multipliers. The shaded area represents the $90 \%$ confidence bands. 


\section{FIGURE 8B. Foreign share and trade openness: U.S. output multiplier}
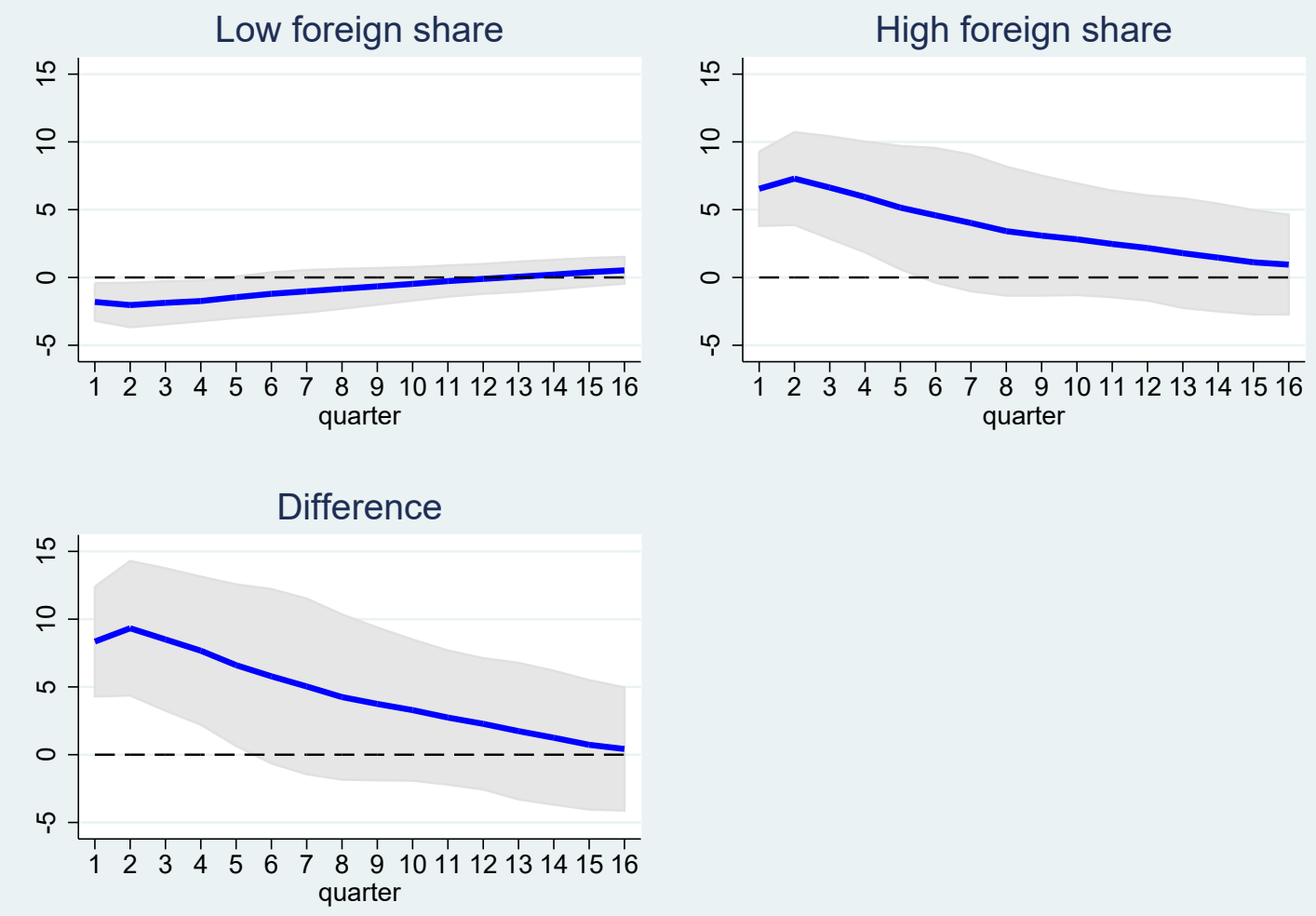

Notes: Cumulative GDP multipliers from a defense news shock equal to 1\% of GDP for low (10th percentile of foreign holdings in the sample) and high (90th percentile of foreign holdings in the sample) foreign share when trade openness is included as an alternative explanation, and the difference between the two multipliers. The shaded area represents the $90 \%$ confidence bands. 


\section{FIGURE 8C. Foreign share and public debt: U.S. output multiplier}
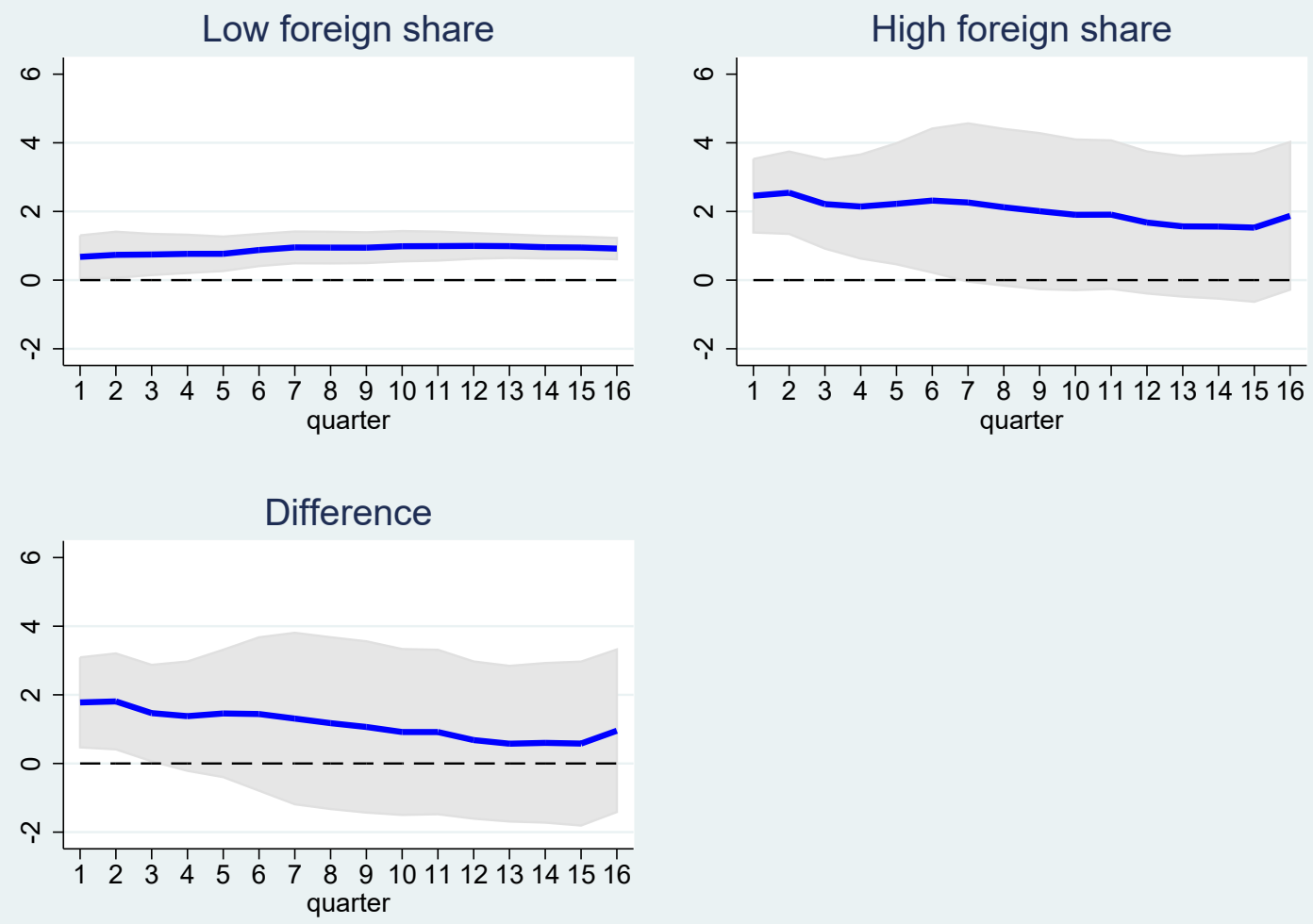

Notes: Cumulative GDP multipliers from a defense news shock equal to 1\% of GDP for low (10th percentile of foreign holdings in the sample) and high (90th percentile of foreign holdings in the sample) foreign share when the public debt-to-GDP ratio is included as an alternative explanation, and the difference between the two multipliers. The shaded area represents the $90 \%$ confidence bands. 
FIGURE 9. International panel: Foreign and domestic public debt holdings (as a \% of GDP)

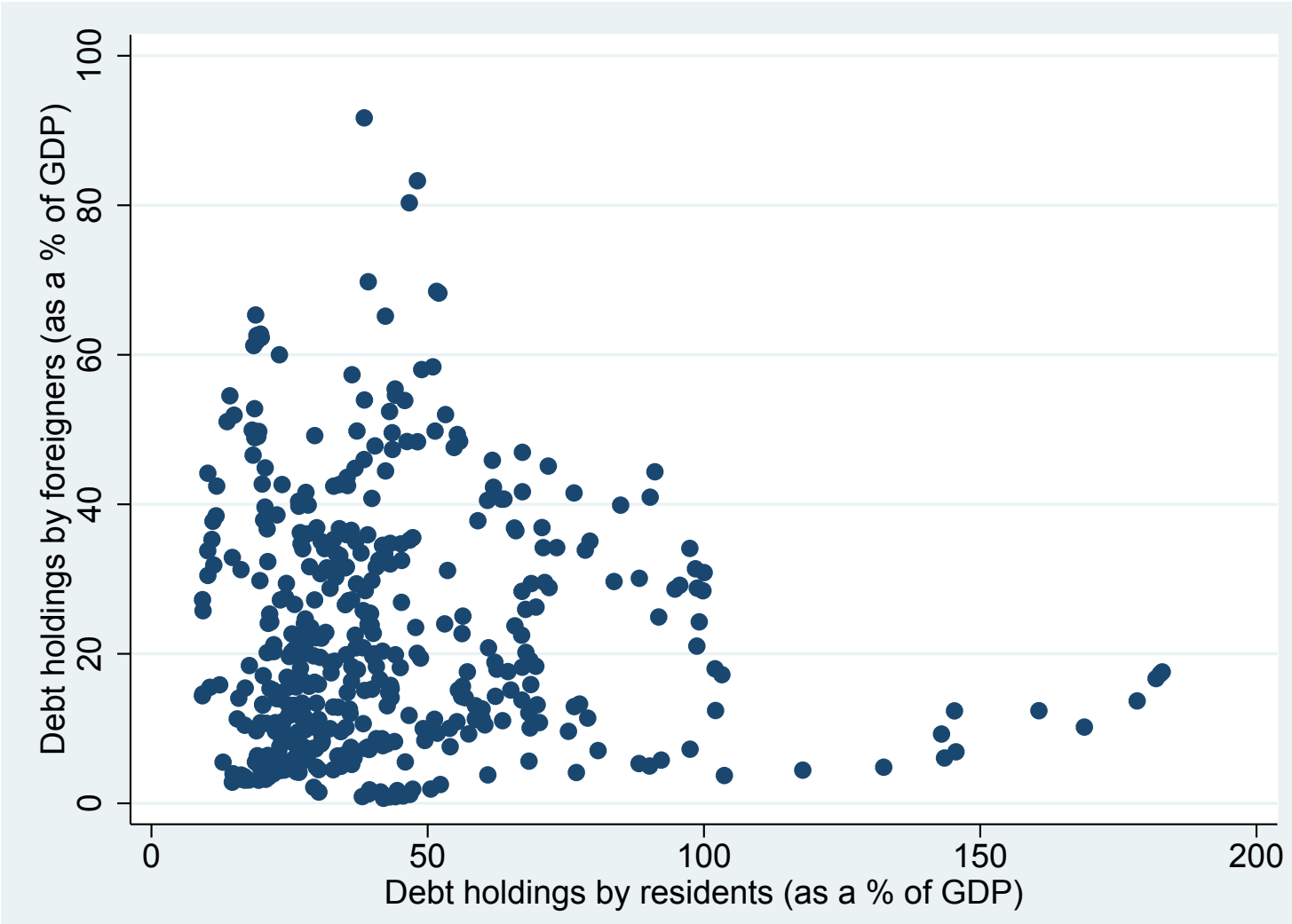

Notes: Foreign and domestic holdings of public debt, as a percentage of GDP. 


\section{FIGURE 10. International panel: Foreign share of public debt holdings}

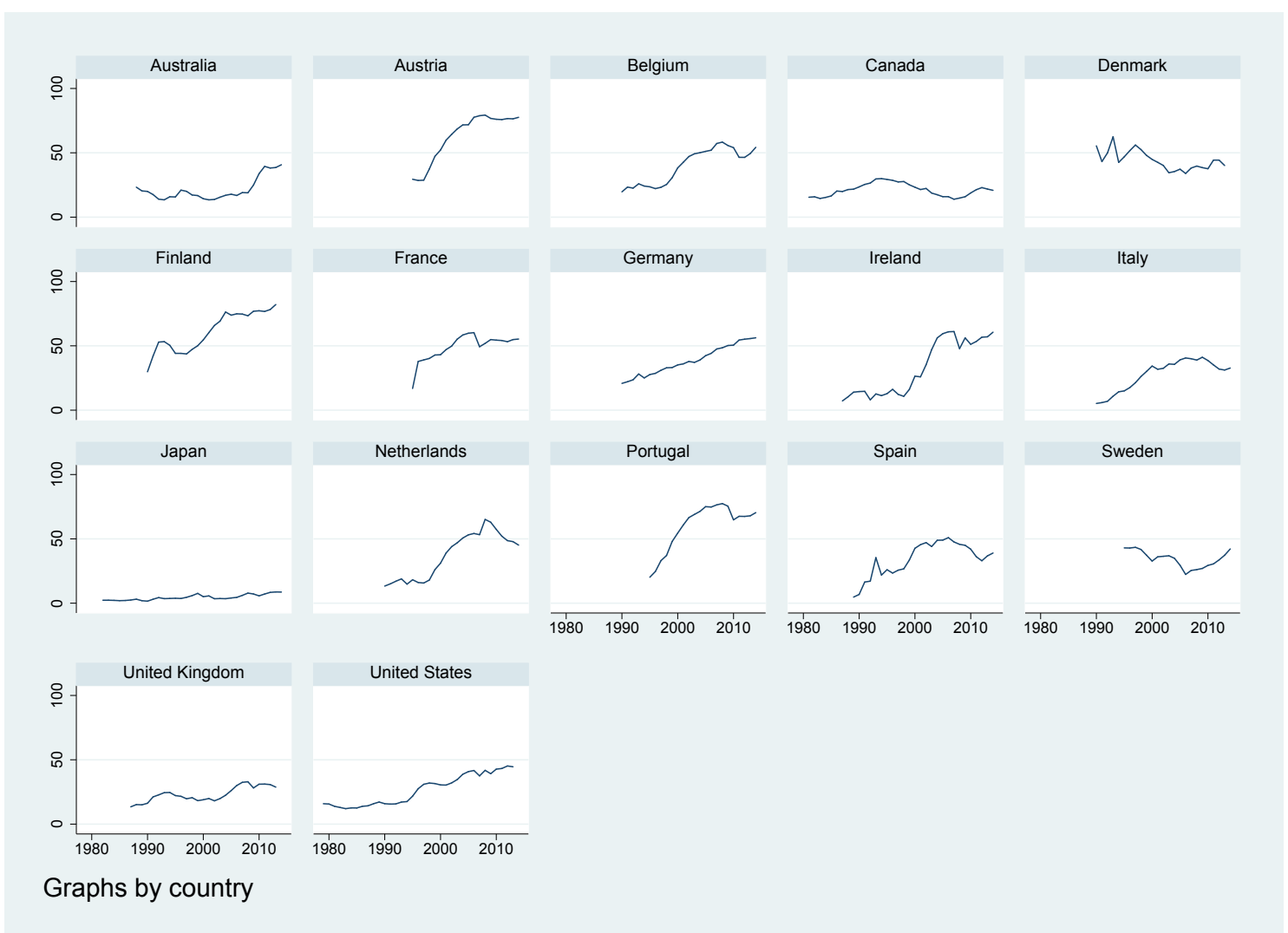

Notes: Foreign share is our measure of foreign holdings of public debt, as a percentage of total public debt. 


\section{FIGURE 11. International panel: Identifed narrative fiscal shocks}
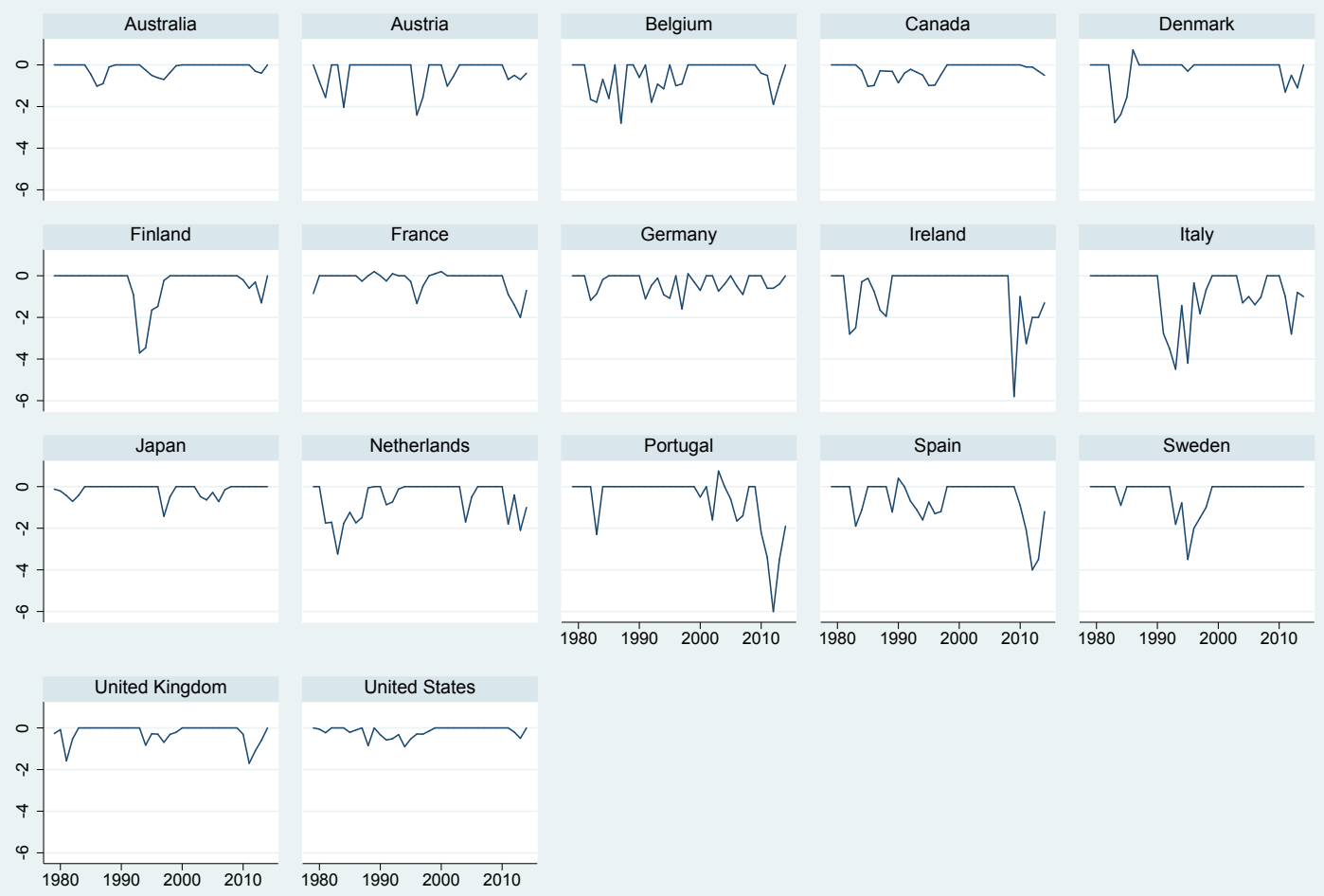

Graphs by country

Notes: The shocks are from Guajardo et al. (2014), updated by Kataryniuk and Valles (2015). The magnitudes of the shocks reflect the expected future budgetary impact of the consolidations, as a percentage of GDP. 
FIGURE 12. International panel baseline model: output multiplier

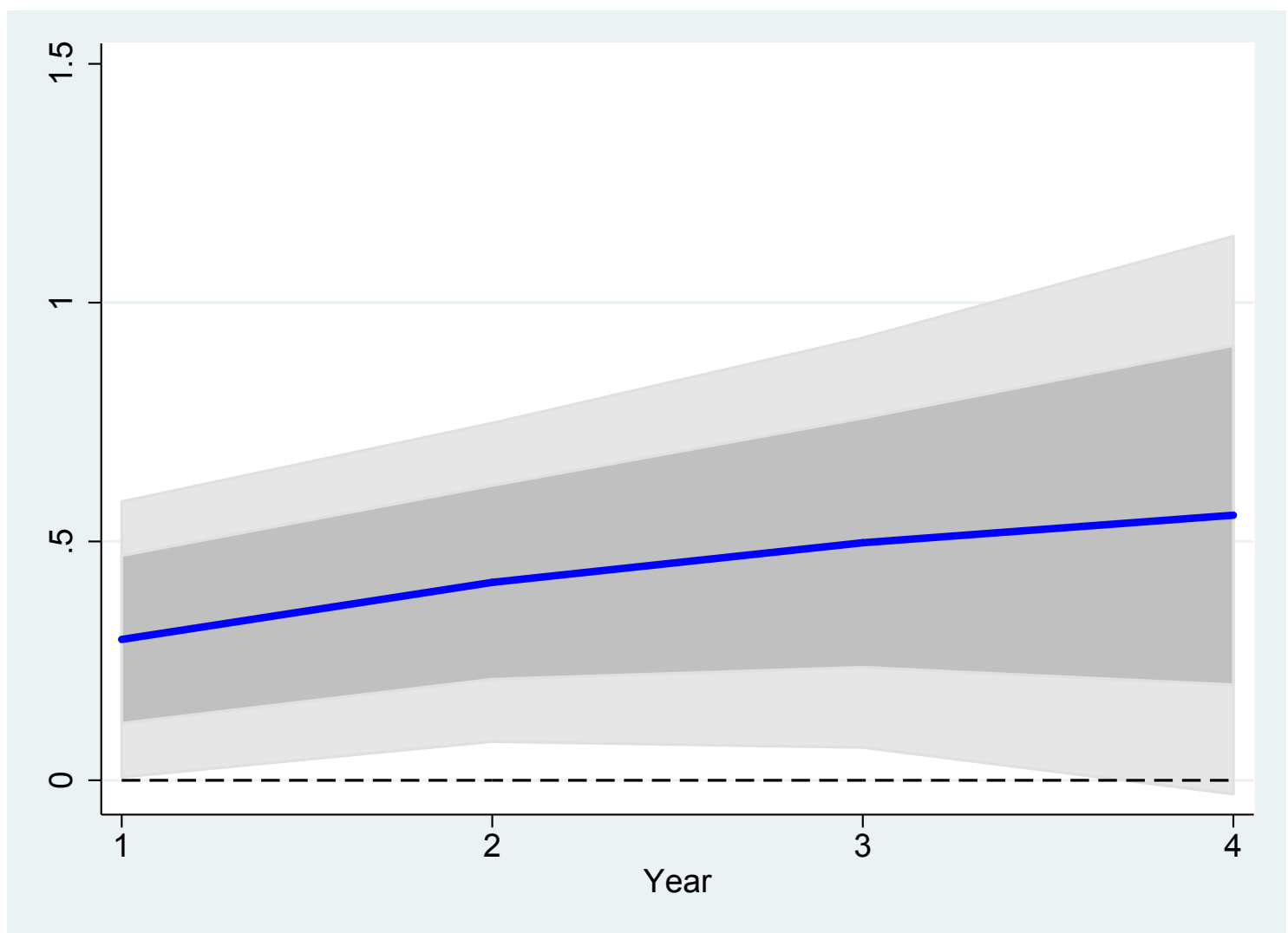

Notes: Cumulative GDP multipliers from a narrative fiscal shock equal to 1\% of GDP. The shaded area represents the $90 \%$ confidence bands. 


\section{FIGURE 13. International panel foreign share: output multiplier}
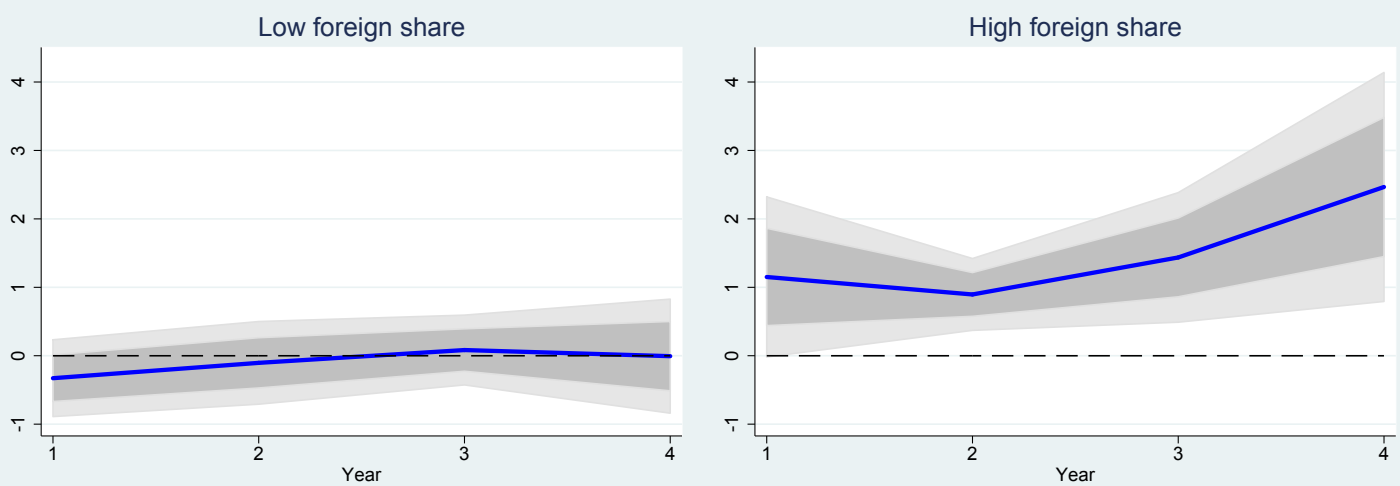

Difference

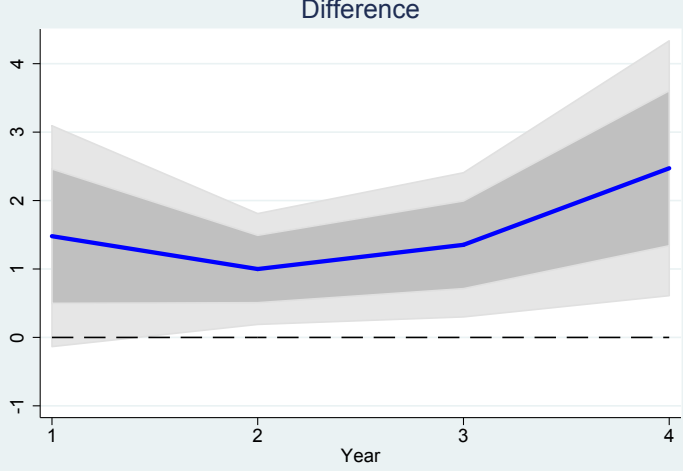

Notes: Cumulative GDP multipliers from a narrative fiscal shock equal to 1\% of GDP for low (10th percentile of foreign holdings in the sample) and high (90th percentile of foreign holdings in the sample) foreign share, and the difference between the two multipliers. The shaded area represents the $90 \%$ confidence bands. 
TABLE 1. Summary statistics for identified U.S. fiscal shocks

\begin{tabular}{lrr}
\hline \hline & defense news shocks & Estimated shocks \\
\hline No. of observations & 255 & 255 \\
Mean & 0.0041 & 0.0008 \\
Median & 0.0000 & 0.0007 \\
Standard deviation & 0.0114 & 0.0029 \\
Minimum & -0.0913 & -0.0071 \\
Maximum & 0.0635 & 0.0131 \\
\hline \hline
\end{tabular}

Notes: The defense news shocks are from Ramey and Zubairy (2018). The

Blanchard-Perotti shocks are the residuals from our estimation of a structural VAR a la

Blanchard and Perotti (2002). Both shocks are normalized by potential GDP. 


\section{TABLE 2. Predictive ability of average foreign share}

\begin{tabular}{|c|c|c|}
\hline & United States & International Panel \\
\hline & $\Delta$ Foreign holdings & $\Delta$ Foreign holdings \\
\hline \multirow[t]{2}{*}{$\Delta$ Total debt } & 0.02 & $0.134^{* * *}$ \\
\hline & $(0.034)$ & $(0.059)$ \\
\hline \multirow[t]{2}{*}{ Foreign share } & $0.003^{*}$ & $-0.63^{* * *}$ \\
\hline & $(0.001)$ & $(0.134)$ \\
\hline \multirow[t]{2}{*}{$\Delta$ Total debt $\cdot$ Foreign share } & $0.878^{* * *}$ & $0.767^{* * *}$ \\
\hline & $(0.170)$ & $(0.124)$ \\
\hline Seasonal dummies & Yes & No \\
\hline Year dummies & No & Yes \\
\hline Country fixed effects & No & Yes \\
\hline Observations & 253 & 421 \\
\hline
\end{tabular}


TABLE 3. Baseline model: U.S. output multiplier

\begin{tabular}{lcccc}
\hline \hline & $\begin{array}{c}(1) \\
\text { Quarter } \mathrm{t}+1\end{array}$ & $\begin{array}{c}(2) \\
\text { Quarter } \mathrm{t}+2\end{array}$ & $\begin{array}{c}(3) \\
\text { Quarter } \mathrm{t}+3\end{array}$ & $\begin{array}{c}(4) \\
\text { Quarter } \mathrm{t}+4\end{array}$ \\
\hline Fiscal shock \\
& $0.91^{* * *}$ & $0.89^{* * *}$ & $0.76^{* * *}$ & $0.62^{* * *}$ \\
& $(0.29)$ & $(0.29)$ & $(0.24)$ & $(0.23)$ \\
\hline Other controls & Yes & Yes & Yes & Yes \\
Obs. & 254 & 254 & 253 & 252 \\
\hline \hline & $(5)$ & $(6)$ & $(7)$ & $(8)$ \\
& Quarter $\mathrm{t}+5$ & Quarter $\mathrm{t}+6$ & Quarter $\mathrm{t}+7$ & Quarter $\mathrm{t}+8$ \\
\hline Fiscal shock & $0.52^{* *}$ & $0.49^{*}$ & 0.46 & 0.40 \\
& $(0.25)$ & $(0.28)$ & $(0.30)$ & $(0.31)$ \\
\hline Other controls & Yes & Yes & Yes & Yes \\
Obs. & 251 & 250 & 249 & 248 \\
\hline \hline
\end{tabular}

Notes: The fiscal shock is government expenditure instrumented by the defense news shocks from Ramey and Zubairy (2018) and the residuals from our estimation of a structural VAR a la Blanchard and Perotti (2002). Both shocks are normalized by potential GDP. Standard errors in parentheses. ${ }^{*} p<0.10,{ }^{* *} p<0.05,{ }^{* * *} p<0.01$ 
TABLE 4. Foreign share: U.S. output multiplier

\begin{tabular}{|c|c|c|c|c|}
\hline & $\begin{array}{c}(1) \\
\text { Quarter } t+1\end{array}$ & $\begin{array}{c}(2) \\
\text { Quarter } t+2\end{array}$ & $\begin{array}{c}\text { (3) } \\
\text { Quarter } t+3\end{array}$ & $\begin{array}{c}(4) \\
\text { Quarter } t+4\end{array}$ \\
\hline Fiscal shock $_{t}$ & $\begin{array}{c}0.34 \\
(0.44)\end{array}$ & $\begin{array}{c}0.35 \\
(0.43)\end{array}$ & $\begin{array}{c}0.33 \\
(0.35)\end{array}$ & $\begin{array}{c}0.26 \\
(0.31)\end{array}$ \\
\hline Fiscal shock $_{t} \cdot$ Foreign share ${ }_{t-1}$ & $\begin{array}{c}5.80^{* * *} \\
(1.88)\end{array}$ & $\begin{array}{c}6.26^{* * *} \\
(1.92)\end{array}$ & $\begin{array}{c}5.76^{* * *} \\
(1.74)\end{array}$ & $\begin{array}{c}5.54^{* * *} \\
(1.74)\end{array}$ \\
\hline Other controls & Yes & Yes & Yes & Yes \\
\hline Observations & 254 & 254 & 253 & 252 \\
\hline & $\begin{array}{c}(5) \\
\text { Quarter } t+5\end{array}$ & $\begin{array}{c}\text { (6) } \\
\text { Quarter } t+6\end{array}$ & $\begin{array}{c}(7) \\
\text { Quarter } \mathrm{t}+7\end{array}$ & $\begin{array}{c}\text { (8) } \\
\text { Quarter } \mathrm{t}+8\end{array}$ \\
\hline Fiscal shock $_{t}$ & $\begin{array}{c}0.19 \\
(0.33)\end{array}$ & $\begin{array}{c}0.22 \\
(0.35)\end{array}$ & $\begin{array}{c}0.25 \\
(0.37)\end{array}$ & $\begin{array}{c}0.27 \\
(0.39)\end{array}$ \\
\hline Fiscal shock $_{t} \cdot$ Foreign share Fi-1 $_{t}$ & $\begin{array}{l}5.64^{* * *} \\
(2.03)\end{array}$ & $\begin{array}{l}5.48^{* *} \\
(2.28)\end{array}$ & $\begin{array}{l}5.14^{* *} \\
(2.46)\end{array}$ & $\begin{array}{l}4.57^{*} \\
(2.52)\end{array}$ \\
\hline Other controls & Yes & Yes & Yes & Yes \\
\hline Observations & 251 & 250 & 249 & 248 \\
\hline \multicolumn{5}{|c|}{$\begin{array}{l}\text { Notes: The fiscal shock is government expenditure instrumented by the defense news from Ramey and } \\
\text { Zubairy (2018) and the residuals from our estimation of a structural VAR a la Blanchard and Perotti } \\
\text { (2002). Both shocks are normalized by potential GDP. Foreign share is our measure of foreign holdings } \\
\text { of public debt, as a percentage of total public debt. Standard errors in parentheses. }{ }^{*} p<0.10,{ }^{* *} p<0.05 \text {, } \\
{ }^{* * *} p<0.01\end{array}$} \\
\hline
\end{tabular}


TABLE 5. International panel baseline model: output multiplier

\begin{tabular}{lcccc}
\hline \hline & $\begin{array}{c}(1) \\
\text { Year } \mathrm{t}+1\end{array}$ & $\begin{array}{c}(2) \\
\text { Year } \mathrm{t}+2\end{array}$ & $\begin{array}{c}(3) \\
\text { Year } \mathrm{t}+3\end{array}$ & $\begin{array}{c}(4) \\
\text { Year } \mathrm{t}+4\end{array}$ \\
\hline Fiscal shock & $0.29^{*}$ & $0.41^{* *}$ & $0.50^{*}$ & 0.56 \\
& $(0.18)$ & $(0.20)$ & $(0.26)$ & $(0.36)$ \\
\hline Other controls & Yes & Yes & Yes & Yes \\
Observations & 576 & 558 & 540 & 523 \\
\hline \hline
\end{tabular}


TABLE 6. International panel foreign share: output multiplier

\begin{tabular}{lcccc}
\hline \hline & $(1)$ & $(2)$ & $(3)$ & $(4)$ \\
& Year $\mathrm{t}+1$ & Year $\mathrm{t}+2$ & Year $\mathrm{t}+3$ & Year $\mathrm{t}+4$ \\
\hline Fiscal shock & -0.69 & -0.35 & -0.25 & -0.61 \\
& $(0.56)$ & $(0.46)$ & $(0.40)$ & $(0.67)$ \\
Fiscal shock $_{t} \cdot$ Foreign share $_{t-1}$ & 2.77 & $1.87^{* *}$ & $2.54^{* *}$ & $4.64^{* *}$ \\
& $(1.84)$ & $(0.92)$ & $(1.20)$ & $(2.12)$ \\
\hline Other controls & Yes & Yes & Yes & Yes \\
Observations & 405 & 387 & 369 & 352 \\
\hline \hline
\end{tabular}

Notes: The fiscal shock is cyclically-adjusted primary deficit instrumented by the narrative narrative shocks from Guajardo et al. (2014), updated by Kataryniuk and Valles (2015). The magnitudes of the shocks reflect the expected future budgetary impact of the consolidations, as a percentage of GDP. Foreign share is our measure of foreign holdings of public debt as a percentage of total public debt. Standard errors in parentheses. ${ }^{*} p<0.10,{ }^{* *} p<0.05$, ${ }^{* * *} p<0.01$ 


\section{A Data definition and sources: United States}

We expand the quarterly dataset compiled by Ramey and Zubairy (2018) to include our measure of the foreign share, as well as private consumption, private investment and net exports. The availability of data for our foreign share measure means our sample runs from 1951:Q3 to 2015:Q1. Below we provide a brief overview of the data sources and their definitions.

Population is from the Federal Reserve Bank of St. Louis FRED database (FRED series: POP'); Government spending is government consumption expenditure and gross investment from the BEA (NIPA Table 1.1.3 line 22); defense news shocks comes from Ramey (2016); Nominal Output is nominal GDP from the BEA (NIPA Table 1.1.5 line 1); Real Output is real GDP from the BEA (NIPA Table 1.1.3 line 1); Potential output is computed as the HPfiltered real GDP; Estimated shocks are the residuals from a structural VAR with government spending and real GDP (and their lags) as macroeconomic determinants; Public debt is the U.S. federal government's treasury securities liabilities (FRED series: FGTSUSQ027S). As this is only available from the first quarter of 1970, we use the longer quarterly series provided by Ramey and Zubairy (2018). The two series overlap almost perfectly during the period they are both available; Foreign share is computed as the rest of the world's treasury securities assets (FRED series: ROWTSEQ027S) as a proportion of the U.S. public debt; Private consumption is from the BEA(NIPA Table 1.1.3 line 2); Private investment is from the BEA (NIPA Table 1.1.3 line 7); Net exports is exports of goods and services from the BEA (NIPA Table 1.1.3 line 16) minus imports of goods and services from the BEA (NIPA Table 1.1.3 line 19); Current account is the balance on current account from the BEA (NIPA Table 4.1 line 31). 


\section{B Instrument relevance: United States}

We use instrumental variable regressions to examine how foreign holdings of public debt affect the size of U.S. fiscal multipliers. We report here the first-stage regression results, related to the (secondstage) regression results discussed in Section 4. The results in Tables A.1 and A.2 correspond to the estimation of the instruments on U.S. government expenditure and U.S. government expenditure interacted with our measure of foreign share respectively. Ramey and Zubairy (2018) demonstrate that a combination of the defense news shock and a shock derived from the Blanchard and Perotti (2002) VAR specification delivers the most relevant instruments for the analysis of U.S. government spending multipliers. They find that this holds for both the linear and state-dependent cases. We therefore use both fiscal shocks to instrument government spending. In the tables, "news shock" represents $\epsilon_{t}^{N}$ and the "estimated shock" is $\epsilon_{t}^{V}$. When interacted with the foreign share variable

they represent the $\epsilon_{t}^{N} \cdot X_{t-1}$ and $\epsilon_{t}^{V} \cdot X_{t-1}$ terms from the first-stage regressions in Section 4 . The first-stage results show that the interaction of the fiscal shocks and foreign share are statistically significant in both regressions.

\section{[INSERT TABLE A.1]}

\section{[INSERT TABLE A.2]}

However, the instrumental variable approach is invalid if the instruments are irrelevant or have only weak relevance. Tests of underidentification assess whether instruments are relevant, while tests of weak identification examine whether instruments are weak. Although there are many methods to conduct these tests, they are not all appropriate for our analysis. Our use of more than one endogenous variable rules out the Staiger and Stock (1997) test of weak identification, as well as the Olea and Pflueger (2013) test used by Ramey and Zubairy (2018). Stock and Yogo (2005) provide critical values for multiple endogenous regressors and multiple instruments, but assume conditional homoskedastic error terms.

Instead, we use the test statistics from Kleibergen and Paap (2006) and Sanderson and Windmeijer (2016). The Kleibergen-Paap rk Wald statistic allows for tests of weak identification when there are more than one endogenous variable and the errors are heteroskedastic and serially correlated. This is the test statistic reported in Table A.3. This test, however, is only formally justified in the context of underidentified, and not weak, instruments. Sanderson and Windmeijer (2016) 
provides tests of weak and underidentification for each endogenous regressor separately. ${ }^{1}$ The results for the Sanderson and Windmeijer (2016) weak and underidentification tests are in Tables A.4 and A.5 respectively. Sanderson and Windmeijer (2016) note that the Stock and Yogo (2005) critical values can be used for their conditional F-statistics. For our case of two endogenous regressors and four instruments, the critical values for the Stock and Yogo (2005) weak ID test are:

- $5 \%$ maximal IV relative bias: 11.04

- $10 \%$ maximal IV relative bias: 7.56

- $20 \%$ maximal IV relative bias: 5.57

- $30 \%$ maximal IV relative bias: 4.73

- $10 \%$ maximal IV size : 16.87

- $15 \%$ maximal IV size: 9.93

- $20 \%$ maximal IV size: 7.54

- $25 \%$ maximal IV size: 6.28

[INSERT TABLE A.3]

[INSERT TABLE A.4]

[INSERT TABLE A.5]

Taken together, the results in Tables A.3, A.4 and A.5 show that our identified (defense news and Blanchard-Perotti) shocks are relevant instruments for the integral of government spending. This is particularly the case when government spending is interacted with our foreign share variable. We therefore believe they are suitable for use in the empirical analysis.

\section{Data definition and sources: International Panel}

\section{C.1 Macroeconomic data}

To maximize consistency across countries, we collect as many macroeconomic variables as possible from the OECD's Economic Outlook No. 95, from November 2015. Due to the availability of the fiscal shock data, our maximum sample period runs from 1978 to 2014.

\footnotetext{
${ }^{1}$ For the weak identification test, the critical values are only available for the i.i.d. case.
} 
All countries Population is the total population (OECD series: POP); Government spending is the volume of final government expenditure (OECD series: CGV); Nominal Output is nominal GDP (OECD series: NGDP); Real Output is nominal output divided by the GDP deflator (OECD series: PGDP); Potential output is computed as the HP-filtered real GDP; Budget deficit is the value of the cyclically-adjusted primary balance (OECD series: NLGXA); Private consumption is the volume of final private consumption expenditure (OECD series: CPV); Private investment is the volume of private total fixed capital formation (OECD series: IPV); Net exports is the value of exports of goods and services (OECD series: NX) minus the value of imports of goods and services (OECD series: NM).

\section{C.2 Net capital flows}

The data on net capital flows comes from the Financial Account of the IMF's Balance of Payments Statistics. In order to stretch the sample back in time, we merge data from two different methodologies (BMP5 and BMP6) for several countries.

Australia: International Monetary Fund, Balance of Payments, Financial Account. 1978-1989: BMP5, Haver code: N193F95Y@IMFBOPA 1990-2014: BMP6, Haver code: B193F00Y@IMFBOPA

Austria: International Monetary Fund, Balance of Payments, Financial Account. 1978-2004: BMP5, Haver code: N122F95Y@IMFBOPA 2005-2014: BMP6, Haver code: B122F00Y@IMFBOPA

Belgium: International Monetary Fund, Balance of Payments, Financial Account. 2005-2014: BMP6, Haver code: B124F00Y@IMFBOPA

Canada: International Monetary Fund, Balance of Payments, Financial Account. 1978-2014: BMP6, Haver code: B156F00Y@IMFBOPA

Denmark: International Monetary Fund, Balance of Payments, Financial Account. 1978-2014: BMP6, Haver code: B128F00Y@IMFBOPA 
Finland: International Monetary Fund, Balance of Payments, Financial Account. 1978-2014: BMP6, Haver code: B172F00Y@IMFBOPA

France: International Monetary Fund, Balance of Payments, Financial Account. 1978-2014: BMP6, Haver code: B132F00Y@IMFBOPA

Germany: International Monetary Fund, Balance of Payments, Financial Account. 1978-2014: BMP6, Haver code: B134F00Y@IMFBOPA

Ireland: International Monetary Fund, Balance of Payments, Financial Account. 1978-2004: BMP5, Haver code: N178F95Y@IMFBOPA 2005-2014: BMP6, Haver code: B178F00Y@IMFBOPA

Italy: International Monetary Fund, Balance of Payments, Financial Account. 1978-2014: BMP6, Haver code: B136F00Y@IMFBOPA

Japan: International Monetary Fund, Balance of Payments, Financial Account. 1978-1995: BMP5, Haver code: N158F95Y@IMFBOPA 1996-2014: BMP6, Haver code: B158F00Y@IMFBOPA

Netherlands: International Monetary Fund, Balance of Payments, Financial Account. 1978-2014: BMP6, Haver code: B138F00Y@IMFBOPA

Portugal: International Monetary Fund, Balance of Payments, Financial Account. 1978-2014: BMP6, Haver code: B182F00Y@IMFBOPA

Spain: International Monetary Fund, Balance of Payments, Financial Account. 1978-2014: BMP6, Haver code: B184F00Y@IMFBOPA

Sweden: International Monetary Fund, Balance of Payments, Financial Account. 1978-2014: BMP6, Haver code: B144F00Y@IMFBOPA 
United Kingdom: International Monetary Fund, Balance of Payments, Financial Account 1978-2014: BMP6, Haver code: B112F00Y@IMFBOPA

United States: International Monetary Fund, Balance of Payments, Financial Account. 1978-2014: BMP6, Haver code: B111F00Y@IMFBOPA

\section{C.3 Exchange rates}

All capital flow data are in U.S. dollars. We convert to national currency values using exchange rates provided by the Federal Reserve Board (FRB). We use the average annual exchange rate from the FRB G.5 release. Data for the euro area countries only begins in 1980. Before this, we use the individual national currencies to US dollar exchange rate and divide it by the individual national currency to euro exchange rate.

Australia: Federal Reserve Board, Foreign Exchange Rates.

1978-2014: Australian Dollar / US Dollar foreign exchange rate. Haver code: A193@FXRATES

Austria: Federal Reserve Board, Foreign Exchange Rates.

1978-1979: Belgian Franc / US Dollar foreign exchange rate (Haver code: FXBLG@USECON) divided by Belgium-Luxembourg Franc / Euro foreign exchange rate (Haver code: X126EXR@EUDATA) 1980-2014: Synthetic Euro / US Dollar foreign exchange rate. Haver code: A122@FXRATES

Belgium: Federal Reserve Board, Foreign Exchange Rates. 1978-1979: Austrian Schilling / US Dollar foreign exchange rate (Haver code: FXAST@USECON) divided by Austrian Schilling / Euro foreign exchange rate (Haver code: X122EXR@EUDATA) 1980-2014: Synthetic Euro / US Dollar foreign exchange rate. Haver code: A124@FXRATES

Canada: Federal Reserve Board, Foreign Exchange Rates.

1978-2014: Canadian Dollar / US Dollar foreign exchange rate. Haver code: A156@FXRATES

Denmark: Federal Reserve Board, Foreign Exchange Rates. 1978-2014: Danish Krone / US Dollar foreign exchange rate. Haver code: A128@FXRATES 
Finland: Federal Reserve Board, Foreign Exchange Rates.

1978-1979: Finnish Markka / US Dollar foreign exchange rate (Haver code: FXFIN@USECON) divided by Finnish Markka / Euro foreign exchange rate (Haver code: X172EXR@EUDATA) 1980-2014: Synthetic Euro / US Dollar foreign exchange rate. Haver code: A172@FXRATES

France: Federal Reserve Board, Foreign Exchange Rates. 1978-1979: French Franc / US Dollar foreign exchange rate (Haver code: FXFR@USECON) divided by French Franc / Euro foreign exchange rate (Haver code: X132EXR@EUDATA) 1980-2014: Synthetic Euro / US Dollar foreign exchange rate. Haver code: A132@FXRATES

Germany: Federal Reserve Board, Foreign Exchange Rates. 1978-1979: German Deutschmark / US Dollar foreign exchange rate (Haver code: FXGER@USECON) divided by German Deutschmark / Euro foreign exchange rate (Haver code: X134EXR@EUDATA) 1980-2014: Synthetic Euro / US Dollar foreign exchange rate. Haver code: A134@FXRATES

Ireland: Federal Reserve Board, Foreign Exchange Rates. 1978-1979: Irish Pound / US Dollar foreign exchange rate (Haver code: FXIRL@USECON) divided by Irish Pound / Euro foreign exchange rate (Haver code: X178EXR@EUDATA) 1980-2014: Synthetic Euro / US Dollar foreign exchange rate. Haver code: A178@FXRATES

Italy: Federal Reserve Board, Foreign Exchange Rates. 1978-1979: Italian Lira / US Dollar foreign exchange rate (Haver code: FXITL@USECON) divided by Italian Lira / Euro foreign exchange rate (Haver code: X136EXR@EUDATA) 1980-2014: Synthetic Euro / US Dollar foreign exchange rate. Haver code: A136@FXRATES

Japan: Federal Reserve Board, Foreign Exchange Rates. 1978-2014: Japanese Yen / US Dollar foreign exchange rate. Haver code: A158@FXRATES

Netherlands: Federal Reserve Board, Foreign Exchange Rates. 1978-1979: Dutch Guilder / US Dollar foreign exchange rate (Haver code: FXNET@USECON) divided by Dutch Guilder / Euro foreign exchange rate (Haver code: X138EXR@EUDATA) 
1980-2014: Synthetic Euro / US Dollar foreign exchange rate. Haver code: A138@FXRATES

Portugal: Federal Reserve Board, Foreign Exchange Rates.

1978-1979: Portuguese Escudo / US Dollar foreign exchange rate (Haver code: FXPOR@USECON) divided by Portuguese Escudo / Euro foreign exchange rate (Haver code: X182EXR@EUDATA) 1980-2014: Synthetic Euro / US Dollar foreign exchange rate. Haver code: A182@FXRATES

Spain: Federal Reserve Board, Foreign Exchange Rates.

1978-1979: Spanish Peseta / US Dollar foreign exchange rate (Haver code: FXSPA@USECON) divided by Spanish Peseta / Euro foreign exchange rate (Haver code: X184EXR@EUDATA) 1980-2014: Synthetic Euro / US Dollar foreign exchange rate. Haver code: A184@FXRATES

Sweden: Federal Reserve Board, Foreign Exchange Rates. 1978-2014: Swedish Krona / US Dollar foreign exchange rate. Haver code: A144@FXRATES

United Kingdom: Federal Reserve Board, Foreign Exchange Rates. 1978-2014: British Pound / US Dollar foreign exchange rate. Haver code: A112@FXRATES

\section{C.4 Public debt}

Where possible, we use total general government debt. We extend the series back by gathering data directly from domestic and international sources.

Australia: Non-consolidated general government debt. Millions of national currency. Final quarter taken as the annual value.

1988-2014: Financial Account by Institutional Sector, Flow of Funds. Haver code: AUNFLGGD@ANZ.

Austria: Sum of government debt held by residents and non-residents. Millions of national currency. European Central Bank Statistical Data Warehouse.

1995-2014: Variable codes:

GFS.A.N.AT.W2.S13.S1.C.L.LE.GD.T._Z.XDC._T.F.V.N._T (residents);

GFS.A.N.AT.W1.S13.S1.C.L.LE.GD.T._Z.XDC._T.F.V.N._T (non-residents). 
Belgium: Consolidated gross debt of General Government. Millions of national currency. 1990-2014: National Bank of Belgium. Haver code: BEAFD@BENELUX.

Canada: Gross debt of the general government. Millions of national currency. 1981-2014: International Monetary Fund, World Economic Outlook Database. Haver code: A156GDS@IMFWEO.

Denmark: 1990-1991: Sum of short- and long-term general government debt. Millions of national currency. European Central Bank Statistical Data Warehouse. Variable codes: GST.A.DK.N.B0X13.MJS.B1300.SA.N_T (short-term debt); GST.A.DK.N.B0X13.MJM.B1300.SA.N (long-term debt). 1992-2014: Gross debt of the general government. International Monetary Fund, World Economic Outlook Database. Haver code: A128GDS@IMFWEO.

Finland: Gross debt of the (consolidated) general government. Millions of national currency. 1990-2014: Statistics Finland.

France: Sum of government debt held by residents and non-residents, consolidating for within general government holdings. Millions of national currency. 1995-2014: European Central Bank Statistical Data Warehouse. Variable codes: GFS.A.N.FR.W2.S13.S1.C.L.LE.GD.T._Z.XDC._T.F.V.N._T (residents); GFS.A.N.FR.W1.S13.S1.C.L.LE.GD.T._Z.XDC._T.F.V.N._T (non-residents); GFS.A.N.FR.W2.S13.S13.CI.L.LE.GD.T._Z.XDC._T.F.V.N._T (intra general government).

Germany: Consolidated General Government liabilities. Millions of national currency. 1990-20014: European Central Bank Statistical Data Warehouse. Variable code: GST.A.DE.N.B0000.MAL.B1300.SA.E. Data for year 1990 was extracted from the Bruegel dataset on sovereign holdings.

Ireland: Holdings of long-term government bonds by sectors. Millions of national currency. 1987-2014: Central Bank of Ireland, Securities Statistics. Sum of resident sectors holdings and 
Nonresident sector holdings.

Italy: Consolidated General Government Debt. Millions of national currency. 1980-2014: Banca d'Italia. Sum of government debt held by resident and non-resident sectors. Datastream variable codes: ITNPD6@ITALY (debt held by Banca d'Italia); ITNPD8@ITALY (debt held by Other Resident MFIs); ITNPD8@ITALY (debt held by Other Resident Financial Institutions); ITNPD12@ITALY (debt held by Other Residents); ITNPD14@ITALY (debt held by Nonresidents).

Japan: Sum of government domestic law bonds, foreign law bonds and T-bills. Billions of national currency.

1982-2014: Bank of Japan Database, Public Finance. Data code: PF'PFGD11 (government bonds, domestic law); PF'PFGD12 (government bonds, foreign law); PF'PFGD@01 (government T-bills).

Netherlands: Gross General Government Debt. Millions of national currency. 1990-2014: European Central Bank Statistical Data Warehouse. Variable codes: GST.A.NL.N.B0000.MAL.B1300.SA.E

Portugal: Gross General Government Debt. Millions of national currency. 1995-2014: European Central Bank Statistical Data Warehouse. Variable codes: GST.A.PT.N.B0000.MAL.B1300.SA.E

Spain: General Government securities. Millions of national currency. 1989-2014: Statistical Bulletin of Bank of Spain. Financial Accounts: Securities holdings by institutional sectors. Sum of all domestic sectors (code: BE_3_13.4) and Rest of the World (code: BE_3_13.29), minus intra-government holdings (code: BE_3_13.19).

Sweden: Gross General Government Debt. Millions of national currency. 1995-2014: European Central Bank Statistical Data Warehouse. Sum of liabilities vis-a-vis resident and Nonresident sectors. Variable codes:

GFS.A.N.SE.W1.S13.S1.C.L.LE.GD.T._Z.XDC._T.F.V.N._T (Domestic excl. General government); GFS.A.N.SE.W2.S13.S1.C.L.LE.GD.T_Z.XDC._T.F.V.N._T (Rest of the World); 
GFS.A.N.SE.W2.S13.S13.CI.L.LE.GD.T._Z.XDC._T.F.V.N._T (Intra-General government).

United Kingdom: Long-term bonds of the Central Government. Millions of national currency. Fourth quarter taken as the annual value. Office of National Statistics.

1987-2013: Variable code: AF.3321: CP NSA

United States: Federal Government, Treasury securities liabilities. Millions of national currency.

1978-2014: Federal Reserve Bank of St. Louis FRED database. FRED series: FGTSUSQ027S. Fourth quarter taken as the annual value.

\section{C.5 Foreign share}

This is the foreign holdings of total public debt, as described above. We extend the series back by gathering data directly from domestic and international sources.

Australia: Liabilities of the public sector (general government) held by the rest of the world. Millions of national currency.

1988-2014: Australian Bureau of Statistics, Balance of Payments and International Investment Position, Foreign Debt Levels, Table 30. Series ID: A3374931F.

Austria: General Government debt held by non-residents. Millions of national currency. 1995-2014: European Central Bank Statistical Data Warehouse.

Variable code: GFS.A.N.AT.W1.S13.S1.C.L.LE.GD.T._Z.XDC._T.F.V.N._T.

Belgium: Consolidated gross debt of the general government, held by the rest of the world. Millions of national currency.

1990-1994: Bruegel dataset on sovereign bond holdings. Based on data from the European Central Bank Statistical Data Warehouse.

1995-2014: Government debt held by non-residents. European Central Bank Statistical Data Warehouse. Variable code: GFS.A.N.BE.W1.S13.S1.C.L.LE.GD.T._Z.XDC._T.F.V.N._T

Canada: Portfolio investment in government bonds by foreigners. Millions of national cur- 
rency.

1981-2014: Statistics Canada, International Investment Position, Table 376-0143.

Denmark: Liabilities of the public sector (general government) held by the rest of the world. Millions of national currency. Statistics Denmark, International Investment Position.

1980-1997: annual data. 1999-2014: Final quarter taken as the annual value. 1998: Linear interpolation between the 1997 and 1999 values.

Finland: Consolidated General Government held by the rest of the world. Millions of national currency.

1990-1994: Bruegel dataset on sovereign bond holdings. Based on data from the European Central Bank Statistical Data Warehouse.

1995-2014: General Government debt held by non-residents. Millions of national currency. Statistics Finland, annual financial accounts. Sum of bonds (AF32) and loans (AF4).

France: Government debt held by non-residents. Millions of national currency. 1995-2014: European Central Bank Statistical Data Warehouse. Variable code: GFS.A.N.FR.W1.S13.S1.C.L.LE.GD.T._Z.XDC._T.F.V.N._T.

Germany: General Government Financial stocks at nominal value held by the rest of the world. Millions of national currency.

1990-1994: Bruegel dataset on sovereign bond holdings. Based on data from the European Central Bank Statistical Data Warehouse.

1995-2014: European Central Bank Statistical Data Warehouse.

Variable code: GST.A.DE.N.B2000.MAL.B1300.SA.E.

Ireland: Holdings of long-term government bonds by non-residents. Millions of national currency.

1978-2014: Central Bank of Ireland, Securities Statistics.

Italy: General Government Debt held by Nonresidents. Millions of national currency. 1988-2014: Banca d'Italia. Datastream code: ITNPD14@ITALY. 
Japan: Sum of foreign holdings of government T-bills, central government securities, local government securities and public corporation securities. Billions of national currency.

1982-2014: Bank of Japan Database, Flow of Funds. Data code: FF'FOF_93FFYS500A310 (government T-bills); FF'FOF_93FFYS500A311 (central government securities); FF'FOF_93FFYS500A312 (local government securities); FF'FOF_93FFYS500A313 (public corporation securities).

Netherlands: Consolidated gross debt of the general government, held by Rest of the world. Millions of national currency.

1990-1994: Bruegel dataset on sovereign bond holdings. Based on data from the European Central Bank Statistical Data Warehouse.

1995-2014: European Central Bank Statistical Data Warehouse.

Variable code: GFS.A.N.NL.W1.S13.S1.C.L.LE.GD.T._Z.XDC_R_B1GQ._T.F.V.N._T.

Portugal: Consolidated gross debt of the general government, held by Rest of the world. Millions of national currency.

1995-2014: European Central Bank Statistical Data Warehouse.

Variable code: GFS.A.N.PT.W1.S13.S1.C.L.LE.GD.T._Z.XDC_R_B1GQ._T.F.V.N._T.

Spain: General Government securities held by Rest of the world. Millions of national currency. 1989-2014: Statistical Bulletin of Bank of Spain. Financial Accounts: Securities holdings by institutional sectors.Variable code: BE_3_13.29.

Sweden: Government debt held by non-residents. Millions of national currency. 1995-2014: European Central Bank Statistical Data Warehouse.

Variable code: GFS.A.N.SE.W1.S13.S1.C.L.LE.GD.T._Z.XDC._T.F.V.N._T.

United Kingdom: Long-term bonds of the central government, held by the rest of the world. Millions of national currency.

1987-2013: Office of National Statistics.

United States: Federal government's treasury securities liabilities, held by the rest of the 
world. Millions of national currency.

1978-2014: Federal Reserve Bank of St. Louis FRED database. FRED series: ROWTSEQ027S.

\section{Instrument relevance: International Panel}

As for the U.S., we use instrumental variable regressions to examine how foreign holdings of public debt affect the size of fiscal multipliers in our panel of advanced economies. We report here the first-stage regression results, related to the (second-stage) regression results discussed in Section 6. The results in Tables A.6 and A.7 correspond to the estimation of the instruments on the cyclically-adjusted primary balance and the cyclically-adjusted primary balance interacted with our measure of foreign share respectively. We use the narrative fiscal shock produced by Guajardo et al. (2014) and subsequently updated by Kataryniuk and Valles (2015) to instrument government spending. The first-stage results show that the interaction of the fiscal shocks and foreign share are statistically significant in both regressions.

[INSERT TABLE A.6]

[INSERT TABLE A.7]

To assess the relevance of our instruments, we follow our approach for the U.S. and use the test statistics from Sanderson and Windmeijer (2016). The results for the weak and underidentfiication tests are in Tables A.8 and A.9 respectively. Sanderson and Windmeijer (2016) note that the Stock and Yogo (2005) critical values can be used for their conditional F-statistics. For our case of two endogenous regressors and two instruments, the critical values for the Stock and Yogo (2005) weak ID test are:

- $10 \%$ maximal IV size: 7.03

- $15 \%$ maximal IV size: 4.48

- $20 \%$ maximal IV size: 3.95

- $25 \%$ maximal IV size: 3.63

[INSERT TABLE A.8] 


\section{[INSERT TABLE A.9]}

Taken together, the results in Tables A.8 and A.9 show that our instruments are relevant. We therefore believe they are suitable for use in the empirical analysis. 
Table A1: U.S. government spending instruments

\begin{tabular}{|c|c|c|c|c|c|c|c|c|}
\hline & $\mathrm{t}+1$ & $\mathrm{t}+2$ & $\mathrm{t}+3$ & $\mathrm{t}+4$ & $\mathrm{t}+5$ & $\mathrm{t}+6$ & $\mathrm{t}+7$ & $\mathrm{t}+8$ \\
\hline News shock $t$ & $\begin{array}{l}-0.00 \\
(0.02)\end{array}$ & $\begin{array}{c}0.05 \\
(0.03)\end{array}$ & $\begin{array}{l}0.13^{* *} \\
(0.06)\end{array}$ & $\begin{array}{l}0.25^{* *} \\
(0.10)\end{array}$ & $\begin{array}{c}0.44^{* * *} \\
(0.16)\end{array}$ & $\begin{array}{c}0.66^{* * *} \\
(0.23)\end{array}$ & $\begin{array}{c}0.89^{* * *} \\
(0.29)\end{array}$ & $\begin{array}{c}1.11^{\text {*** }} \\
(0.35)\end{array}$ \\
\hline News shock $_{t} \cdot$ Foreign share $t-1$ & $\begin{array}{l}-0.01 \\
(0.07)\end{array}$ & $\begin{array}{l}-0.22 \\
(0.17)\end{array}$ & $\begin{array}{l}-0.50 \\
(0.33)\end{array}$ & $\begin{array}{l}-1.00^{*} \\
(0.54)\end{array}$ & $\begin{array}{c}-1.79^{* *} \\
(0.83)\end{array}$ & $\begin{array}{c}-2.65^{* *} \\
(1.17)\end{array}$ & $\begin{array}{c}-3.49^{* *} \\
(1.49)\end{array}$ & $\begin{array}{r}-4.29^{* *} \\
(1.76)\end{array}$ \\
\hline $\mathrm{BP}$ shock $_{t}$ & $\begin{array}{c}1.95^{* * *} \\
(0.08)\end{array}$ & $\begin{array}{c}2.99^{* * *} \\
(0.21)\end{array}$ & $\begin{array}{c}4.03^{* * *} \\
(0.33)\end{array}$ & $\begin{array}{c}5.12^{* * *} \\
(0.50)\end{array}$ & $\begin{array}{c}6.08^{* * *} \\
(0.75)\end{array}$ & $\begin{array}{c}7.15^{* * *} \\
(1.04)\end{array}$ & $\begin{array}{c}8.08^{* * *} \\
(1.39)\end{array}$ & $\begin{array}{c}8.97^{* * *} \\
(1.75)\end{array}$ \\
\hline BP shock $_{t} \cdot$ Foreign share ${ }_{t-1}$ & $\begin{array}{c}0.67 \\
(0.52)\end{array}$ & $\begin{array}{c}0.65 \\
(1.09)\end{array}$ & $\begin{array}{c}1.03 \\
(1.84)\end{array}$ & $\begin{array}{c}2.29 \\
(2.93)\end{array}$ & $\begin{array}{c}4.26 \\
(4.49)\end{array}$ & $\begin{array}{c}5.59 \\
(6.13)\end{array}$ & $\begin{array}{c}7.39 \\
(8.05)\end{array}$ & $\begin{array}{c}9.92 \\
(10.05)\end{array}$ \\
\hline Observations & 254 & 254 & 253 & 252 & 251 & 250 & 249 & 248 \\
\hline
\end{tabular}


Table A2: Interacted U.S. government spending instruments

\begin{tabular}{|c|c|c|c|c|c|c|c|c|}
\hline & $\mathrm{t}+1$ & $\mathrm{t}+2$ & $\mathrm{t}+3$ & $\mathrm{t}+4$ & $\mathrm{t}+5$ & $\mathrm{t}+6$ & $\mathrm{t}+7$ & $\mathrm{t}+8$ \\
\hline News shock $t$ & $\begin{array}{l}-0.01^{*} \\
(0.00)\end{array}$ & $\begin{array}{l}-0.01 \\
(0.01)\end{array}$ & $\begin{array}{l}-0.01 \\
(0.01)\end{array}$ & $\begin{array}{l}-0.02 \\
(0.02)\end{array}$ & $\begin{array}{l}-0.02 \\
(0.02)\end{array}$ & $\begin{array}{l}-0.02 \\
(0.03)\end{array}$ & $\begin{array}{l}-0.02 \\
(0.03)\end{array}$ & $\begin{array}{l}-0.02 \\
(0.04)\end{array}$ \\
\hline News shock $_{t} \cdot$ Foreign share ${ }_{t-1}$ & $\begin{array}{l}0.03^{* *} \\
(0.01)\end{array}$ & $\begin{array}{l}0.06^{*} \\
(0.03)\end{array}$ & $\begin{array}{l}0.11^{*} \\
(0.06)\end{array}$ & $\begin{array}{l}0.14^{*} \\
(0.08)\end{array}$ & $\begin{array}{c}0.13 \\
(0.09)\end{array}$ & $\begin{array}{c}0.16 \\
(0.12)\end{array}$ & $\begin{array}{c}0.20 \\
(0.15)\end{array}$ & $\begin{array}{c}0.25 \\
(0.17)\end{array}$ \\
\hline BP shock $_{t}$ & $\begin{array}{l}-0.00 \\
(0.01)\end{array}$ & $\begin{array}{c}0.01 \\
(0.02)\end{array}$ & $\begin{array}{c}0.01 \\
(0.03)\end{array}$ & $\begin{array}{l}-0.00 \\
(0.04)\end{array}$ & $\begin{array}{l}-0.00 \\
(0.05)\end{array}$ & $\begin{array}{c}0.00 \\
(0.07)\end{array}$ & $\begin{array}{c}0.01 \\
(0.09)\end{array}$ & $\begin{array}{l}-0.01 \\
(0.11)\end{array}$ \\
\hline BP $\operatorname{shock}_{t} \cdot$ Foreign share ${ }_{t-1}$ & $\begin{array}{c}2.06^{* * *} \\
(0.08) \\
\end{array}$ & $\begin{array}{c}2.97^{* * *} \\
(0.17) \\
\end{array}$ & $\begin{array}{c}3.95^{* * *} \\
(0.28) \\
\end{array}$ & $\begin{array}{c}5.21^{* * *} \\
(0.39)\end{array}$ & $\begin{array}{c}6.39^{* * *} \\
(0.50)\end{array}$ & $\begin{array}{c}7.59^{* * *} \\
(0.70)\end{array}$ & $\begin{array}{c}8.76^{* * *} \\
(0.89)\end{array}$ & $\begin{array}{c}10.22^{* * *} \\
(1.10)\end{array}$ \\
\hline Observations & 254 & 254 & 253 & 252 & 251 & 250 & 249 & 248 \\
\hline
\end{tabular}

Notes: The dependent variable is U.S. government spending interacted with our measure of foreign share. The (defense) news shocks are from Ramey and Zubairy (2018). The BP shocks are the residuals from our estimation of a structural VAR

a la Blanchard and Perotti (2002). Both shocks are normalized by potential GDP. Standard errors in parentheses. ${ }^{*} p<0.10$, ${ }^{* *} p<0.05,{ }^{* * *} p<0.01$ 
Table A3: Weak identification test: Kleibergen-Paap Wald rk F statistic $h \quad$ U.S. government spending Interacted U.S. government

\begin{tabular}{lcc} 
& F-statistic & spending F-statistic \\
\hline \hline 1 & 624.0 & 369.9 \\
2 & 235.1 & 81.8 \\
3 & 149.5 & 61.7 \\
4 & 127.1 & 48.6 \\
5 & 108.6 & 45.3 \\
6 & 90.2 & 37.6 \\
7 & 77.5 & 32.8 \\
8 & 66.6 & 28.9 \\
9 & 57.9 & 25.9 \\
10 & 49.3 & 23.1 \\
11 & 43.4 & 21.5 \\
12 & 37.7 & 19.8 \\
13 & 34.7 & 14.4 \\
14 & 33.1 & 10.5 \\
15 & 31.2 & 7.6 \\
16 & 28.9 & 6.6 \\
\hline
\end{tabular}

Notes: The third column is U.S. government spending interacted with our measure of foreign share. We use both the defense news and the Blanchard-Perotti shocks as instruments. 
Table A4: Sanderson and Windmeijer (2016) weak identification test statistics $h \quad$ U.S. government Interacted U.S. government U.S. government Interacted U.S. government spending F-statistic spending F-statistic spending $\mathrm{p}$-value $\quad$ spending $\mathrm{p}$-value

\begin{tabular}{lcccc}
\hline \hline 1 & 483.5 & 428.7 & 0.000 & 0.000 \\
2 & 117.9 & 363.6 & 0.000 & 0.000 \\
3 & 87.1 & 287.7 & 0.000 & 0.000 \\
4 & 69.9 & 255.9 & 0.000 & 0.000 \\
5 & 63.7 & 192.2 & 0.000 & 0.000 \\
6 & 53.6 & 134.4 & 0.000 & 0.000 \\
7 & 46.9 & 103.4 & 0.000 & 0.000 \\
8 & 42.0 & 75.0 & 0.000 & 0.000 \\
9 & 37.8 & 66.9 & 0.000 & 0.000 \\
10 & 33.9 & 61.8 & 0.000 & 0.000 \\
11 & 31.0 & 50.8 & 0.000 & 0.000 \\
12 & 27.3 & 22.6 & 0.000 & 0.000 \\
13 & 26.7 & 18.7 & 0.000 & 0.000 \\
14 & 25.9 & 14.4 & 0.000 & 0.000 \\
15 & 25.3 & 10.7 & 0.000 & 0.000 \\
16 & 24.3 & 8.9 & 0.000 & \\
\hline
\end{tabular}

Notes: The second and fourth columns are U.S. government spending interacted with our measure of foreign share. We use both the defense news and the Blanchard-Perotti shocks as instruments. The p-values are from the first-stage regressions and assume i.i.d. errors. 
Table A5: Sanderson and Windmeijer (2016) underidentification chi-squared statistics $h \quad$ U.S. government Interacted U.S. government U.S. government Interacted U.S. government chi-squared statistic spending chi-squared statistic spending p-value spending p-value

\begin{tabular}{lcccc}
\hline \hline 1 & 1666.9 & 1478.2 & 0.000 & 0.000 \\
2 & 406.7 & 1253.6 & 0.000 & 0.000 \\
3 & 300.4 & 992.5 & 0.000 & 0.000 \\
4 & 241.3 & 883.5 & 0.000 & 0.000 \\
5 & 219.9 & 663.9 & 0.000 & 0.000 \\
6 & 185.5 & 464.4 & 0.000 & 0.000 \\
7 & 162.1 & 357.7 & 0.000 & 0.000 \\
8 & 145.4 & 259.5 & 0.000 & 0.000 \\
9 & 131.0 & 231.8 & 0.000 & 0.000 \\
10 & 117.4 & 214.1 & 0.000 & 0.000 \\
11 & 107.6 & 176.3 & 0.000 & 0.000 \\
12 & 94.6 & 78.4 & 0.000 & 0.000 \\
13 & 92.6 & 64.9 & 0.000 & 0.000 \\
14 & 90.2 & 50.0 & 0.000 & 0.000 \\
15 & 88.1 & 37.1 & 0.000 & 0.000 \\
16 & 84.7 & 30.9 & 0.000 & 0.000 \\
\hline
\end{tabular}

Notes: The second and fourth columns are U.S. government spending interacted with our measure of foreign share. We use both the defense news and the Blanchard-Perotti shocks as instruments. The p-values are from the first-stage regressions and assume i.i.d. errors. 
Table A6: International panel fiscal variable instruments

\begin{tabular}{|c|c|c|c|c|}
\hline & $\begin{array}{c}(1) \\
\text { Year } t+1\end{array}$ & $\begin{array}{c}(2) \\
\text { Year } t+2\end{array}$ & $\begin{array}{c}(3) \\
\text { Year } t+3\end{array}$ & $\begin{array}{c}(4) \\
\text { Year } t+4\end{array}$ \\
\hline Narrative shock $_{t}$ & $\begin{array}{c}0.73^{* * *} \\
(0.17)\end{array}$ & $\begin{array}{c}0.50 \\
(0.39)\end{array}$ & $\begin{array}{c}1.29^{* * *} \\
(0.41)\end{array}$ & $\begin{array}{l}1.18^{* *} \\
(0.49)\end{array}$ \\
\hline${\text { Narrative } \operatorname{shock}_{t} \cdot \text { Foreign share }}_{t-1}$ & $\begin{array}{l}-0.45 \\
(0.31)\end{array}$ & $\begin{array}{c}1.03 \\
(0.81)\end{array}$ & $\begin{array}{l}-0.51 \\
(0.96)\end{array}$ & $\begin{array}{l}-0.45 \\
(1.03)\end{array}$ \\
\hline Observations & 405 & 387 & 369 & 352 \\
\hline
\end{tabular}

Notes: The dependent (fiscal) variable is the cyclically-adjusted primary balance. The shocks are from Guajardo et al. (2014), updated by Kataryniuk and Valles (2015). The magnitudes of the shocks reflect the expected future budgetary impact of the consolidations, as a percentage of GDP. Standard errors in parentheses. ${ }^{*} p<0.10,{ }^{* *} p<0.05,{ }^{* * *} p<0.01$ 


\section{Table A7: International panel interacted fiscal variable instruments}

\begin{tabular}{|c|c|c|c|c|}
\hline & $\begin{array}{c}(1) \\
\text { Year } t+1\end{array}$ & $\begin{array}{c}(2) \\
\text { Year } t+2\end{array}$ & $\begin{array}{c}(3) \\
\text { Year } \mathrm{t}+3\end{array}$ & $\begin{array}{c}(4) \\
\text { Year } t+4\end{array}$ \\
\hline Narrative shock $t$ & $\begin{array}{c}0.12 \\
(0.08)\end{array}$ & $\begin{array}{c}-0.17 \\
(0.11)\end{array}$ & $\begin{array}{c}-0.06 \\
(0.15)\end{array}$ & $\begin{array}{c}-0.05 \\
(0.14)\end{array}$ \\
\hline Narrative shock $_{t} \cdot$ Foreign share $t-1$ & $\begin{array}{c}0.15 \\
(0.23)\end{array}$ & $\begin{array}{c}1.57^{* * *} \\
(0.36)\end{array}$ & $\begin{array}{l}1.31^{* *} \\
(0.56)\end{array}$ & $\begin{array}{l}1.24^{* *} \\
(0.49)\end{array}$ \\
\hline Observations & 405 & 387 & 369 & 352 \\
\hline
\end{tabular}

Notes: The dependent (fiscal) variable is the fiscal variable is the cyclically-adjusted primary balance interacted with our measure of foreign share. The shocks are from Guajardo et al. (2014), updated by Kataryniuk and Valles (2015). The magnitudes of the shocks reflect the expected future budgetary impact of the consolidations, as a percentage of GDP. Standard errors in parentheses. ${ }^{*} p<0.10$, ${ }^{* *} p<0.05,{ }^{* * *} p<0.01$ 
Table A8: International panel: Sanderson-Windmeijer chi-square statistics and p-values $h \quad$ Fiscal variable Interacted fiscal variable Fiscal variable Interacted fiscal variable chi-squared statistic chi-squared statistic

\begin{tabular}{lcccc}
\hline \hline 1 & 12.2 & 4.3 & 0.001 & 0.051 \\
2 & 6.4 & 13.3 & 0.018 & 0.001 \\
3 & 20.5 & 19.8 & 0.000 & 0.000 \\
4 & 13.1 & 18.8 & 0.001 & 0.000 \\
\hline \multicolumn{7}{l}{ Notes: The dependent (fiscal) variable is the cyclically-adjusted primary balance. The second and fourth columns } \\
are the fiscal variable interacted with our measure of foreign share. The shocks are from Guajardo et al. (2014), \\
\multicolumn{7}{l}{ updated by Kataryniuk and Valles (2015). The p-values are from the first-stage regressions and assume i.i.d. errors. }
\end{tabular}


Table A9: International panel: Sanderson-Windmeijer F statistics and p-values $\mathrm{h}$ Fiscal variable Interacted fiscal variable Fiscal variable Interacted fiscal variable $\begin{array}{cccc}\text { F-statistic } & \text { F-statistic } & \text { p-value } & \text { p-value }\end{array}$

\begin{tabular}{lcccc}
\hline \hline 1 & 10.9 & 3.8 & 0.001 & 0.051 \\
2 & 5.7 & 11.8 & 0.018 & 0.001 \\
3 & 18.2 & 17.6 & 0.000 & 0.000 \\
4 & 11.6 & 16.6 & 0.001 & 0.000 \\
\hline
\end{tabular}

Notes: The dependent (fiscal) variable is the cyclically-adjusted primary balance. The second and fourth columns are the fiscal variable interacted with our measure of foreign share. The shocks are from Guajardo et al. (2014), updated by Kataryniuk and Valles (2015). The p-values are from the first-stage regressions and assume i.i.d. errors. 